\title{
Improving the Design of Conditional Transfer Programs: \\ Evidence from a Randomized Education Experiment in Colombia
}

\section{August 2010}

\begin{abstract}
:
Using a student level randomization, we compare three education-based conditional cash transfers designs: a standard design, a design where part of the monthly transfers are postponed until children have to re-enroll in school, and a design that lowers the reward for attendance but incentivizes graduation and tertiary enrollment. The two non-standard designs significantly increase enrollment rates at both the secondary and tertiary levels while delivering the same attendance gains as the standard design. Postponing some of the attendance transfers to the time of re-enrollment appears particularly effective for the most at-risk children.
\end{abstract}

Keywords: Education, Conditional Cash Transfer, Sibling Effects

JEL Codes: I22, J13, I28 


\section{Introduction}

Conditional cash transfer (CCT) programs have become a popular and effective (see for example, Gertler (2004)) mechanism for incentivizing academic participation. Given the number of programs, there is surprising little variation in their structure. Most are closely inspired by the popular Mexican Conditional Cash Transfer (CCT) program previously known as PROGRESA and now OPORTUNIDADES. Under this program, students are paid on a monthly or bi-monthly basis for meeting a specified attendance (usually 80 percent per month) target.

We test two simple variations on this basic model in the large municipality of Bogota, Colombia, both motivated by the need to prevent dropout from secondary schools and encourage matriculation at tertiary institutions. The first variant aims to relax families' possible savings constraints, such as those due to commitment problems (see for example, Ashraf, Karlan, and Yin (2006)) or imperfect savings institutions. Such savings constraints might be particularly relevant in the education context because of the large expenses families face at the beginning of each new school year. To test the efficacy of this strategy, we compare a basic treatment implemented in a manner very similar to PROGRESA (bi-monthly transfers for good attendance) to a "savings treatment" that varies the timing with which the funds are distributed to families. This treatment distributes 2/3 of the "good attendance" funds on the same bi-monthly basis but distributes the remaining funds for all months in a lump-sum at the time the students are supposed to re-enroll in school.

The other variant directly provides incentives for graduation and tertiary enrollment. In a second experiment, we evaluate a "tertiary treatment” that provides children with the same lower bi-monthly transfers as the savings treatment but then guarantees a large payment upon 
graduation. Students can then receive the payment sooner by matriculating to an institution of higher education.

In each experiment, we use an over-subscription model rather than the basic geographic allocation strategy used in most previous studies. ${ }^{1}$ We staged a large recruitment drive and randomly allocated 7,984 treatments to 13,433 registered children. This model allows us to randomize at the child-level, generating variation within schools and also within families.

We find that changing the structure of these programs can generate significant increases in re-enrollment without weakening incentives to attend, improvements that are largest for the poorest and most academically at-risk students. We find that all of the designs significantly increase attendance, generating gains of 3 to 5 percentage points. Despite the reduced bimonthly transfers, the savings and tertiary treatments increase attendance rates by at least as much as the basic treatment. However, these two non-standard treatments appear superior to the standard CCT payment structure when it comes to increasing enrollment rates at both the secondary and tertiary levels. Within secondary school, just postponing part of the transfer increases re-enrollment by 4 percentage points while the basic treatment has almost no effect. The savings and tertiary treatments also increase matriculation rates at tertiary institutions: the savings treatment increases enrollment by 9.4 percentage points while the tertiary treatment proves particularly effective, increasing matriculation by 48.9 percentage points.

The difference in the performance of the basic and savings treatments is entirely driven by their effects on the most at-risk students. The savings treatment is especially effective at improving the enrollment of the lowest income students and the students with the lowest

\footnotetext{
${ }^{1}$ One exception is the system that the national Colombian government used to allocate school vouchers in the Program de Ampliacion de Cobertura de la Educacion Secunderia (PACES) program (see Angrist et al, 2002 and Angrist et al 2006). While our use of this allocation strategy was a practical solution for conducting a student-level randomization, the intra-family variation in treatment provided by this strategy has direct policy implications for this and other allocation mechanisms that partially treat families, such a those treating only children of a particular age.
} 
participation rates. In comparison, the basic treatment has little effect on these students. This suggests that modifications in the structure of these interventions can also help target resources by better meeting the needs of those students most likely to drop out of school. The tertiary treatment performs similarly to the savings treatment and has a much more significant impact on students who are least likely re-enroll.

We also find some evidence that participation in CCTs may cause a worrisome reallocation of resources within the household. Siblings (particularly sisters) of treated students attend school less frequently and drop out more often than those in families that received no treatment. Overall, a student, who does not receive the treatment but whose sibling does, attends 3 percentage points less and is 7.3 percentage points less likely to re-enroll than a similar student whose sibling remains untreated. For girls, the differences are 5.3 and 10.4 percentage points respectively. This is inconsistent with the view that families use the additional income generated by the CCT program to invest in the education of the non-treated children. In fact, families with a treated child appear to take educational opportunities away from the untreated siblings.

The rest of the paper is organized as follows. First, we describe the educational system in Bogota, Colombia (Section II). Next, we describe the research design, including the design of the individual treatments, the allocation process, the various data sets, and the statistical models. Section IV provides our primary treatment effect estimates on monitored attendance and administrative enrollment. Section V contains estimates of treatment effects on self-reported measures of academic participation and labor market activity from our follow-up survey. And Section VI presents evidence of spillovers onto siblings. We conclude in Section VII. 


\section{Education in Bogota}

Colombia is a relatively typical middle income, Latin American country. Child mortality is relatively low at 21 per 1000 births, and individuals can expect to live long lives -- life expectance at birth is 72.6 years. The per capita income of Colombia is US\$ 2,020, with only 17.8 percent of the population living on less than two dollars per day (World Bank, 2006).

While the central government maintains control of curriculum as well as of the allocation of teachers and their wages, municipalities are primarily responsible for the administration of public education using national funds. The central government provides resources to municipalities, primarily from income and VAT taxes, and close to 90 percent of these funds are required by law to go toward health and education. With these funds, municipalities must develop, maintain, and run the facilities in their jurisdictions. Municipalities that have greater capacity to collect and administer taxes supplement central resources with local funds, usually from property taxes.

The academic year runs from the end of January until the middle of November. The system is divided into three categories: basic primary (grades one through five), basic secondary (grades six through nine) and middle secondary (grades ten and eleven). After finishing the eleventh grade, children can matriculate to either traditional universities or one of many vocational schools. Children usually start school at five to seven years of age and are legally required to attend school through the ninth grade, a period referred to as basic education.

Like in most urban areas in middle-income countries, school attendance is highest for younger children. The enrollment rate for students between ages 5 and 13 is close to 100 percent. After 13 years old, the attendance rate starts to decline. The average attendance rate for individuals aged 15 is 92 percent, 16 is 90 percent and 17 is 80 percent. The drop is faster for 
low-income individuals. For individuals falling into the bottom two categories of the Colombian poverty index (the SISBEN), the attendance rate for 15 year olds is 84 percent, for 16 year olds is 80 percent and for 17 year olds is 65 percent (Fedesarrollo, 2005). Overall, in 2003, there were 89,000 children between 5 and 18 years of age who were out of school. Seventy-four percent of these were classified in the bottom two categories of the SISBEN (Fedesarrollo, 2005).

When surveyed, students claim that the major reason for dropping out is the cost of education. Students have to pay to re-enroll each year; they also have to pay for required items like uniforms, books, and supplies. In fact, 64 percent of dropouts claim that the high cost of education is the main reason for leaving school (Fedesarrollo, 2005). Enrollment fees, uniforms, and school materials make up 90 percent of the costs for low-income individuals and cost between 24,000 and 50,000 pesos (US\$ 13 to US\$22) depending on the school and grade. This is a large expense given that the poorest families in Bogota earn less than US\$ 750 a year.

\section{Research Design}

In 2005, the city of Bogota established the Conditional Subsidies for School Attendance (“Subsidios Condicionados a la Asistencia Escolar”) program in an effort to increase student retention, lower drop-out rates and reduce child labor. ${ }^{2}$ Hoping to improve the program over the basic conditional cash transfer model, the Secretary of Education of the City (Secretaria de Educacion del Distrito, SED) decided to implement a pilot study in two of the twelve localities in

\footnotetext{
${ }^{2}$ This program is distinct from Families en Accion. Families en Accion is a nationally run Colombian conditional cash transfer program modeled closely on PROGRESA that incentivizes both school participation and health care. At the time that this project was conducted, the program was not functioning within Bogota. See Attanasio et al. (2005) for a more complete description of the program.
} 
the city. The pilot was to run for a year, and then the results would be used to inform the design of the final program that would operate city-wide. ${ }^{3}$

\section{A. Design of Treatments}

Ultimately, three interventions were chosen for the pilot. First, operating as a reference is a basic intervention similar to that used in PROGRESA/OPORTUNIDADES. In this basic model, participants would receive 30,000 pesos per month (approximately US\$ 15) as long as the child attended at least 80 percent of the days that month. Based on the responses to our surveys, the total annual value of the transfer (300,000 pesos) is three times more than what students report on average in labor market earnings and is slightly more than the average 250,000 pesos that families report spending each year on educational expenses. The payments would be made bimonthly through a dedicated debit card run by one of the major banks in Colombia. Students would be removed from the program if they failed to matriculate to the next grade twice, failed to reach the attendance target in two successive bi-monthly periods, or were expelled from school. Finally, all payments would be based on reports provided to the Secretary of Education by the students' principals.

The two additional treatments were experimental variants of this basic intervention aiming to better reach the goals of the program while keeping the cost of each intervention roughly equivalent to the basic intervention. ${ }^{4}$ Based on research that suggests that families may face difficulties saving money for students' education (either because of intra-household

\footnotetext{
${ }^{3}$ The design of the individual treatments was a collaborative effort between the authors and city officials. The goal was to design variations in the standard treatment that were roughly cost equivalent for a student starting the program in grade six and that could be feasibly administered city-wide when the program was scaled up.

${ }^{4}$ The amounts are not exactly the same because the treatments do not account for inflation. However, the inflation rate in 2005 was $4.85 \%$, and the net effect of this difference is to reduce the value of the savings treatment which, we will show, is more effective than the basic treatment despite the slightly lower value.
} 
bargaining, personal discounting issues, or other high costs of savings), the second treatment (savings treatment) varied the timing of the distributions to students' families. Instead of receiving 30,000 pesos a month for reaching the attendance target, students were paid two-thirds of this amount on a bi-monthly basis $(20,000$ pesos or US\$10), while the remaining third was held in a bank account. The accumulated funds were then made available to students' families during the period in which students prepare to enroll for the next school year. If students reached the attendance target every month, this treatment would make 100,000 pesos (US\$ 50) available to them in December. ${ }^{5}$

While keeping the overall cost of the intervention roughly similar to the basic treatment, the savings treatment differs from the basic intervention with respect to both short-term liquidity constraints and the technology available to save for longer-term goals. Because the monthly transfer is reduced, children may attend school less often if their family faces very immediate liquidity constraints, forcing them to trade off time spent in school with time spent at work, for example. However, if families' long-term savings constraints are more significant for children’s academic participation than the more short-term liquidity constraints, the savings treatment could generate as high attendance rates and higher re-enrollment rates than the basic treatment, as families receive all the accrued funds at the time they need money to start a new school year. ${ }^{6}$

The third treatment (tertiary treatment) changes the outcomes upon which students are being incentivized. Instead of only providing an incentive to attend school, this treatment also provides an incentive to graduate and matriculate to a higher education institution. Like in the

\footnotetext{
${ }^{5}$ Subsequent payment of delayed subsidies was not conditional on future attendance. So, if a student earned the subsidy in February but never again met the 80 percent target, the student would still receive the "saved" fraction of the February payment at the end of the calendar year.

${ }^{6}$ This effect would be similar to the effect observed in Duflo, Kremer, and Robinson (2006) in which simply offering farmers the option to buy fertilizer at harvest time, when money was available, significantly increased the purchase of fertilizer.
} 
savings treatment, in the short term, the monthly transfer for good attendance is reduced from 30,000 pesos per month to 20,000 pesos. However, in this case, there is no remaining third being held in an account: the financial reward for good attendance in a given month is being reduced by $1 / 3$. However, upon graduating the student earns the right to receive a transfer of 600,000 pesos (\$US 300), amounting to 73 percent of the average cost of the first year at a vocational school (823,000 pesos or \$US 412). If the student enrolls in a tertiary institution, she receives the transfer immediately; if she fails to enroll upon graduation, she receives the transfer after a year has passed.

Compared to the basic treatment, this tertiary treatment could reduce attendance rates by lowering the reward for attendance if students' short-term liquidity constraints are important (as in the savings treatment). On the other hand, because of the graduation incentives, the tertiary treatment could stimulate higher re-enrollment and graduation rates and possibly higher attendance rates (if attendance is viewed as a relevant input into graduation); it could also result in higher levels of matriculation to tertiary institutions. One should note though that, unlike the savings treatment, the tertiary treatment is only cost-equivalent to the basic treatment from the perspective of a student going through six years of secondary education. In the pilot data we analyze below, this treatment ends up being more generous than the basic treatment because it is applied to students that are three years or less from graduation.

\section{B. Structure of Randomization}

As required by the SED, the assessment of the treatments was divided into two separate experiments located in two very similar localities in Bogota, San Cristobal and Suba. ${ }^{7}$ Eligible

\footnotetext{
${ }^{7}$ It was the SED's decision to segregate the evaluation of the tertiary treatment into single, smaller locality within Bogota because this treatment was more expensive (for students in grades nine through eleven).
} 
registrants in San Cristobal, ranging from grade six through eleven, were randomly assigned between a control group, the basic treatment, and the savings treatment. The tertiary treatment was evaluated separately in an experiment in Suba, where students ranging from grade nine through eleven, were randomly assigned to either the tertiary treatment or a control group. Hence, while we can experimentally estimate the causal effect of the tertiary treatment, we can only identify its relative effect compared to the basic (or saving treatment) by relying on a rich set of socio demographic controls and school-level fixed effects rather than purely random variation. $^{8}$

Both experiments were based on an over-subscription model. The city guaranteed enough funds to provide 7,984 students with the subsidies, 6,851 in the basic-savings experiment in San Cristobal and 1,133 in the tertiary experiment in Suba, for three years. A publicly advertised registration process was held in each locality. Given that there were more interested children than subsidies, the subsidies were allocated to children based on a lottery. ${ }^{9,10}$

In January and early February 2005, the program was advertised in the two localities through posters, newspapers ads, radio spots, loudspeakers in cars, churches, and community leaders, including principals of schools and priests. Potential candidates for the subsidy were registered during a 15 day-period between the end of February and the beginning of March 2005.

\footnotetext{
${ }^{8}$ The pilot also included two additional experiments whose results are not included in this draft due to space constraints. First, the basic treatment was also randomly assigned to students in Suba, but only those in grades six through eight. Second, in both localities, out-of-school children were randomly assigned to a special program designed to facilitate their re-enrollment into school.

${ }^{9}$ The over subscription and recruitment process are similar to the techniques used in the assignment of school vouchers in the PACES program implemented nationally in Colombia. This process is described in Angrist et al. (2002).

${ }^{10}$ One potential concern with random assignment at the child level is that the treatment may spillover between children through peer networks. In estimates that are not presented in this draft, we have investigated this possibility. The baseline survey contained information on children's peers. Using this information, we confirmed first that children in the treatment and control groups have both similar networks and are connected to the same number of treated children. Thus, any indirect treatment effect would be equally distributed across the two groups. Second, however, we also document that there is no effect of a child being friends with a treated child - either overall or among the treatment or control students individually. These results are available upon request.
} 
The registration was conducted in various schools of the two localities. Families were not aware at the time of registration of the existence of different treatments; the conditional transfers were advertized as incentives to participate in school with an annual value equal to at least the annual value of the basic treatment.

In order to be considered for the program, at least one parent or guardian was required to be present at the registration. In order to be eligible for the program, children had to meet several criteria. First, the potential candidates had to have finished grade 5 for the basic-savings experiment and grade 8 for the tertiary experiment and, for both, had to be enrolled but not yet graduated from grade 11. Also, the children's families had to have been classified into the bottom two categories on Colombia's poverty index, the SISBEN. ${ }^{11}$ To verify the classification, the student had to present an identification card (which the vast majority of students have). The SISBEN categorization of the household was confirmed online by the SED at the time of registration. Finally, in order to eliminate the possibility that families would move to take advantage of the program, only those households that had been classified by the SISBEN system as living in San Cristobal or Suba prior to 2004 were eligible to participate in the program. In total, 13,433 eligible students were registered for the two experiments: 10,907 for the basicsavings experiment and 2,526 for the tertiary experiment.

The randomization was publicly conducted on April 4 in each locality. The research team conducted the actual lottery, but in order to ensure transparency of the process, the code was inspected prior to the exercise by researchers from the National University. The randomizations were done publicly (projecting the code onto a screen), with representatives of the community, school and local authorities present. The lists of beneficiaries were immediately printed, signed

\footnotetext{
${ }^{11}$ See Vélez et al (1999) for a more detailed description of SISBEN. The SISBEN classified households according to 6 levels, 1 being assigned to the poorest. Most of the families in these areas were surveyed in 2003 and 2004.
} 
by local officials, and made available to the communities so that parents were able to determine if their children were included.

The randomization was stratified on locality, type of school (public / private), gender, and grade level. Panel A of Table 1 summarizes the distribution of children by grade, gender and experimental groups. In all, 6,851 students from San Cristobal and 1,133 from Suba received one of the treatments. This left 4,056 control students in San Cristobal and1,393 in Suba.

\section{Data}

The data come from six sources. First, we have data from the original SISBEN surveys of 2003 and 2004, which contain information on all the families that were eligible to register for the lottery. These data are subsets of the actual surveys that were used to create the SISBEN national poverty index. We have access to information on all individuals placed into the bottom two SISBEN categories, providing a rich baseline description of all of the eligible families. Among the variables included in the SISBEN data are family-level characteristics such as schooling level of the household head, physical characteristics of the dwelling, employment status of adults, and household income, as well as individual-level variables such as school enrollment status at the time of the survey, age, income, and marital status. ${ }^{12}$

The second source of data comes from the program registration process itself. During this process families had to provide some basic information on the students to ensure eligibility. These data include birth date, gender, last grade completed and year in which that grade was

\footnotetext{
${ }^{12}$ The challenge of using these data is that families knew that they were being surveyed for the purpose of scoring them on a poverty index. As a result, measures of assets and income are probably underestimates of the true values. However, this bias is almost certainly not correlated with the differences investigated in this paper given the timing and purpose of the survey. We use this information for two primary purposes. First, we use it to compare registrants to non-registrants, and second, we use it as a source of information on the households to which the children in the study belong.
} 
completed. Most of this information was verified through the actual SISBEN database and when possible, the SED's official records.

We also obtained administrative records from the SED that includes the enrollment records of every child in a public school and most private schools in the two localities. These data, combined with the demographic data from SISBEN and registration datasets, allow us to assess the effect of the treatments using every student that registered for the randomization. The only students not included in this data set are students who attended a school that did not report enrollment information to the SED or students for whom there was insufficient information in either set of records. Indeed, we were able to match the enrollment status for all but 9.3 percent of the students in the experiment from San Cristobal and 8.5 percent from Suba, and the students for whom a match was not possible were equally divided between the various research groups. On average the difference in match rates between the groups was less than a half a percentage point. $^{13}$

Students within the study were spread across 251 schools, but the density was heavily skewed with the majority of students in a small number of schools. Given the budget constraints, we chose to collect baseline data and subsequent attendance data in only the 68 schools with the largest number of registered children. This implied a total possible sample of 7,569 children. The distribution of these children by grade, gender and experimental group is provided in Panel B of Table 1.

We collected attendance data during the last quarter of 2005 through direct observation. For this purpose, the team assembled a group of assistants who randomly visited schools and

\footnotetext{
${ }^{13}$ In San Cristobal, 9.3 percent of the control children were not matched while 0.41 percent more children in the basic treatment were not matched (the standard error is 0.75 percentage points) and 0.25 less students in the savings treatment were not matched (the standard error is 0.81 percentage points). In Suba, 8.4 percent of control children could not be matched, and in the tertiary treatment group 0.28 percentage points more students could not be matched (the standard error is 1.27 percentage points).
} 
classes. The assistants directly called the roll of all students, and students were marked absent if they were not physically present in the classroom. They visited a total of 1,069 classes in the 68 selected schools for 13 weeks. Attendance data were collected on all 7,569 students.

Finally, we conducted both a baseline and follow-up survey on these students in these 68 schools. The baseline was conducted between May and July, 2005 and comprised a simple selfadministered survey that the students filled out in class. The coverage rate of this survey was very high: of the 7,569 students that were selected for surveying, 7,158 completed the baseline survey. The distribution of these students is provided in Panel C of Table 1. Reassuringly, their distribution across grades, gender and experimental groups is similar to that for the original registrants (Panel A of Table 1$){ }^{14}$

The follow-up survey was conducted in February and March 2006. To ensure that the survey did not preferentially treat students still enrolled in school, we conducted the survey at the household level. For the follow up, the research team located the families of 98 percent of baseline students overall, 98 percent in San Cristobal and 99 percent in Suba. Both the attrition rates and the distribution of attriting students' characteristics were similar across the research groups (see Table A4 in the Appendix).

\section{Analytic Models}

We use a simple difference model that makes comparisons between different subsets of the sample without controlling for any covariates. These comparisons are intended to assess the comparability of different groups such as the research groups, registrants and non-registrants, etc. For the basic-savings experiment, for example, the specification takes the following form:

\footnotetext{
${ }^{14}$ In the Appendix, we provide a careful comparison of the students who provided a baseline survey compared to those who did not (Table A2) and report average characteristics of children across research groups for students who completed the baseline (Table A3).
} 


$$
y_{i j}=\beta_{o}+\beta_{B} \text { Basic }_{i}+\beta_{S} \text { Savings }_{i}+\varepsilon_{i j}
$$

The variable $y_{i j}$ represents a particular characteristic or outcome for child $i$ in school $j$. This is regressed on the variables Basic $_{i}$ and Savings $_{i}$, which are indicator variables for whether or not the child is in the respective treatment group. The error variable $\varepsilon_{i j}$ is indexed with both student and school identifiers because the error terms are allowed to co-vary up to the school level. We also use a difference estimator that controls for socio-demographic and school characteristics. For the basic-savings experiment, this model is specified as follows:

$$
y_{i j}=\beta_{o}+\beta_{B} \text { Basic }_{i}+\beta_{S} \text { Savings }_{i}+\delta X_{i j k}+\phi_{j}+\varepsilon_{i j}
$$

The variables from Equation 1 are defined as before; $X_{i j k}$ is a vector of socio-demographic controls for child $i$ in school $j$ and family $k$ and $\phi_{j}$ are school fixed effects. We again allow the error terms to co-vary up to the school level. We use similar specifications for the tertiary treatment.

The socio-demographic controls include indicators for the households' ownership of assets, access to utilities, possession of durable goods, and physical infrastructure of the house. The child characteristics include age, gender, marital status, years of education, number of years too old (or young) the child is for her grade, and an indicator for whether or not the child is older than normal for her grade. At the family level, we also control for the marital status of the head of household, the head's age and education level, the number of people in the household, the number of children in the household, the household income, the family’s SISBEN score, and a geographic poverty index called the "estrato". We use the same list of controls in all the regressions that include socio-demographic controls. 


\section{E. Baseline Comparison}

As a check that the randomization created balanced research groups, we compare students assigned to the research groups using the information available in the SISBEN survey. All of this information was collected prior to the randomization, and thus, students in each research group should, on average, have similar characteristics in the SISBEN survey.

The results are presented in Table 2, where we use Equation (1) to compare students in each research group using both individual- and household-level characteristics. Most of the estimated differences are too small to be statistically significant. And, even the few statistically significant differences we observe are economically quite small: for example, the savings treatment group has heads of households with two tenths of a year less education than those of the control group. Also, the basic treatment group scores slightly higher than the control group on a household possessions index while the savings groups scores slightly higher than the control group on access to utilities. Overall, we make 60 comparisons and find 7 differences that are statistically significant at the 10 percent level, 5 at the five percent level, and two at the one percent level, consistent with what one would expect from random assignment.

We also performed similar comparisons using just the 68 schools that were selected for attendance monitoring and find similar results. These comparisons are available in Table A1 in the Appendix.

\section{Primary Results: Attendance and Re-enrollment}

\section{A. Attendance}

Table 3 compares attendance rates across experimental groups, using the monitored attendance data that was collected toward the end of the 2005 academic year. The first three columns show 
the results for the basic-saving experiment while the second three columns contain the comparisons for the tertiary experiment. Column 7 pools the data for students in grades nine through eleven to allow a comparison of the treatment effects across all three treatments. The estimated treatment effects are in rows one through three, and the test statistics from comparisons of the relative treatment effects are provided in rows four and five. For the enrollment effects presented in the next section and in Table 4, we restrict the sample to those students in grades 6 through 10 (because those in grade 11 should graduate rather than re-enroll). To be consistent, we exclude students in grade 11 from these estimates as well. ${ }^{15}$

We start with a discussion of the basic-savings experiment. Column 1 provides simple difference estimates of the treatment effect using the Equation (1). We see that the basic treatment increases attendance by 3.3 percentage points (significant at the one percent level) while the savings treatment increases attendance by 2.9 percentage points (also significant at the one percent level). Both interventions are effective, and there is no evidence that the savings treatment is less effective than the basic treatment at boosting attendance, despite the lower monthly payments. In columns 2 and 3, we estimate the same treatment effects using Equation (2) by adding first socio-demographic controls and then school fixed effects. As expected given the random assignment tests presented in Table 2, the estimated treatment effects in columns 2 and 3 are similar to those in column 1.

Columns 4 through 6 of Table 3 report the equivalent estimates for the tertiary experiment. Recall that the tertiary treatment provides the same monthly payment for good attendance as the savings treatment, but, unlike in the savings treatment, there are no delayed transfers here but instead a plain reduction in the direct reward for good attendance. In each specification, the estimated treatment effect is an increase in enrollment of a little more than 5

\footnotetext{
${ }^{15}$ Adding students from grade 11 to these estimates does not change the results.
} 
percentage points (significant at the one and five percent level depending on the specification). A direct comparison of the three programs is attempted in column 7 where we estimate Equation (2) with both demographic controls and school fixed-effects on a sample that includes all Suba students and the subset of San Cristobal students that are in grades 9 to $11 .^{16}$ This specification confirms that the point estimate on the tertiary treatment effect is actually larger than that on the other treatments when estimated on similar samples. However, the difference is not statistically significant (p-value of 0.18 when compared with the basic treatment).

In summary, while both the savings and tertiary treatments might have hurt monthly attendance because of the more binding short-term liquidity constraints they impose on participating families (compared to the basic CCT), we find no evidence of this in the data. Furthermore, while the tertiary treatment provides lower direct rewards for good attendance (but possibly indirect rewards by incentivizing graduation), this treatment appears no less effective than the other two treatments in getting children to come to school every day.

\section{B. Re-enrollment}

We next compare the enrollment rates of students in each research group for the 2006 academic year. These results are presented in Table 4; the layout of this table is identical to that of Table 3. ${ }^{17}$ As in the previous section, we use only students in grades 6 through 10 since students in grade 11 should have graduated in the previous year (we study graduation and tertiary enrollment outcomes in Table 7).

\footnotetext{
${ }^{16}$ It is important to note that the comparison between the tertiary treatment and the other two treatments is not experimental. While the estimated treatment effects for all of the treatments are experimentally based, the comparison to the tertiary treatment occurs across experiments. Thus unlike the comparison between the basic and savings treatments, differences between the other treatments and the tertiary treatment could be due to unobserved heterogeneity in treatment effects despite controlling for a common set of demographic characteristics.

${ }^{17}$ For these estimates, we use data from all of the children in the study, rather than just the 68 schools selected for attendance monitoring. In results not included in this draft (but available upon request), we perform similar estimates using only students from the 68 schools. We find a similar pattern of results.
} 
Recall that in the basic-savings experiment, a third of the bi-monthly payments for good attendance were held in an account until just before the beginning of the next academic year, with the expectation that this might help families face enrollment related expenses. This seems to have happened. The savings treatment significantly increases enrollment by about 4 percentage points (significant at the one percent level) while the basic treatment seems to increase enrollment by only 1.1 to 1.7 percentage points depending on the specification. The difference in magnitude of treatment effects is statistically significant at the five percent level.

Turning next to the tertiary experiment in columns 4 through 6 , we find that the tertiary treatment increases enrollment by 3.7 percentage points. Despite the similar point estimate to the savings treatment, the effect is only statistically significant at the ten percent level, probably due to the small sample size. Comparing the effect to that of the basic treatment in grades nine through ten, the effect of the tertiary treatment is larger, by 4.2 percentage points (the basic treatment has no effect on these students), but the p-value of the F-statistic for a test of the equality of the treatment effects has a p-value of 0.14.

How do these effects compare to prior research on the enrollment effects of conditional cash transfers? Such a comparison is complicated by differences in methodology and target populations across programs. For example, most conditional cash transfer programs provide non-education forms of assistance along with educational incentives (usually for nutrition or health care) and are targeted at more rural populations of students in primary and lower secondary school (usually grades 1-8).

Keeping these caveats in mind, our estimates of the impact of the savings and tertiary treatments on secondary enrollment are in the same range as those measured in other contexts. For example, within the context of the experimental evaluations, Glewwe and Olinto (2004) find 
a 1 to 2 percentage point increment in enrollment for rural students aged 6-13 of a CCT program in Honduras with a transfer of \$5 per student per month. In rural Ecuador, Schady and Araujo (2006) estimates a 3.5 percentage point increase among students aged 6-17 for a monthly transfer of \$15. In Mexico, Schultz (2004) reports a 2.5 percentage point increase in enrollment for boys and 3.5 for girls in grades 1 to 9 for monthly transfers ranging from \$17 to \$32 per month per student. Finally, Attanasio et al (2006) assess, with propensity score matching, a similar program to ours (but one that also includes a nutrition component) run by the national Colombian government and find an increase in self-reported enrollment of 4.8 percentage points for urban children aged $14-17$. The monthly transfers ranged from $\$ 4.61$ to $\$ 9.23$. However, these areas are much less developed than Bogota, and students have a baseline enrollment rate of only 65 percent.

\section{Heterogeneity}

To investigate the possibility of heterogeneity in the programs' effects, we decompose the treatment effects based on the students' gender, income, and projected probability of attendance and enrollment without the treatment. These results are presented in Table 5 and Figures 1 through 4. Table 5 includes estimates for just the basic-savings treatment. The results for the tertiary treatment show the same pattern although the differences are not always statistically significant due to the smaller sample size. ${ }^{18}$

We estimate the effects of the treatments by gender in columns 1 and 2 of Table 5 . Column 1 focuses on attendance; column 2 on enrollment. For attendance, both treatments show the same pattern of effects - boys experience gains of about 5 percentage points while girls experience much smaller gains. In fact, girls experience no statistically significant change in

\footnotetext{
${ }^{18}$ Estimates are available upon request.
} 
attendance due to either treatment. The difference in treatment effects by gender is 3.4 percentage points for the basic treatment (significant at the 10 percent level) and 4.5 percentage points for the savings treatment (significant at the one percent level). This difference in effects by gender may be due to the fact that girls have a 3.2 percentage point higher attendance rate than boys absent the treatments. So, the net effect of the treatments is to increase the attendance rate of boys to roughly that of girls. ${ }^{19}$ There is no gender difference, on the other hand, when it comes to enrollment effects: girls experience the same gain from the savings treatment as boys do and experience no gains due to the basic treatment just like the boys.

Columns 3 and 4 of Table 5 study heterogeneity by income for attendance and enrollment, respectively. In column 3, we estimate Equation (2) interacting the treatment indicators with an indicator for whether or not a child's family falls into the bottom two income terciles (earns less than 380,000 pesos -190 US\$- a month). The estimates suggest that both treatments have a large effect on students that are the least poor (e.g. those in the top tercile) with the basic treatment increasing attendance by 6.7 percent and the savings treatment increasing attendance by 4.7 percentage points (both statistically significant at the 1 percent level). The difference is statistically significant, suggesting that for this group of students the savings treatment does offer slightly weaker incentives to attend regularly. Among the poorer students, the attendance rates for both treatments are significantly smaller, although the treatment effects for these students are still positive and statistically significant. The effect of the basic treatment on these students is 1.7 percentage points (significant at the 10 percent level), and the effect for the savings treatment is 1.8 percentage points (significant at the 5 percent level). ${ }^{20}$

\footnotetext{
${ }^{19}$ There also does not seem to be differential effects of the treatments by gender. Although the decline in the treatment effect for girls is 1.1 percentage points larger for the savings treatment, the difference between the savings and basic treatments' differential gender effects is not statistically significant at conventional levels (p-value 0.36).

${ }^{20}$ These estimates are not presented in the tables, but are available upon request.
} 
When it comes to re-enrollment (column 4 of Table 5), the treatments differ. We find that both the basic and savings treatment increase enrollment among the wealthiest students: the savings treatment increases enrollment by 4.3 percentage points and the basic treatment increases enrollment by 3.1 percentage points (the difference between these effects is not statistically significant at conventional levels). The interaction terms make it clear that the overall average non-effect of the basic treatment on enrollment is being driven by the poorest students in our study. The basic treatment effect among these students is 2.9 percentage points smaller than among the wealthier students, yielding a statistically insignificant 0.2 percentage point increase in enrollment (p-value 0.91). The effect for the savings treatment is about the same as it is for the wealthier students. Thus, for all but the wealthiest students, the savings treatment has an effect that is 3.4 percentage points greater than the savings treatment, a difference that is statistically significant at the 1 percent level (p-value 0.0036). ${ }^{21}$

Finally, we disaggregate the results by predicted attendance and enrollment rates absent the treatment. We estimate these counterfactuals by modeling the behavior of students in our control groups using only the available baseline demographic characteristics. We then, for all students, use the baseline characteristics and the coefficients from the regressions on the control group to project what these students would have done had they not been treated. The baseline demographic characteristics we include in the model are the same as in Equation (2).

Figure 1 shows the non-parametric regression of monitored attendance rates on the predicted attendance rates by research group. The relationship for each treatment is basically identical and suggests gains for students across the distribution. However, the gains are largest for the students who are the least likely to attend. This is tested in column 5 of Table 5. Controlling for the predicted attendance rates, both treatments have similar effects, and these

\footnotetext{
${ }^{21}$ These estimates are available upon request.
} 
effects are largest for those least likely to attend. The effect for students who are very likely to have attended absent the treatment is the sum of the coefficients in row 11 and row 1 (rows 12 and 2 for the savings treatment). The treatments have no effect on these students. However, the basic and savings treatment effects increase by 2.4 and 1.7 percentage points respectively for every ten percentage points less a student would have attended absent the treatment. Those unlikely to have attended experienced gains of 22.5 and 16.5 percentage points. ${ }^{22}$

Figure 2 shows the distribution for enrollment. Unlike the effects for attendance, the two treatments show different patterns. The basic treatment does not consistently generate higher enrollment rates than the control group while the savings treatment does. Further, the savings treatment generates the largest gains for the students with the lowest probability of enrollment. We test these patterns in column 6 of Table 5. The savings treatment effect is largest for those projected not to re-enroll and decreases by 1.6 percentage points for every ten percentage point increase in projected enrollment. In contrast, we detect no statistically significant effect of the basic treatment. Comparing the effects of the two treatments, the difference in the slope and level effect are statistically significant at the 1 percent level. Further, our estimates suggest that for the students most in danger of dropping out (students with a probability of re-enrollment below 0.4 the bottom 13.2 percent of the sample), the savings treatment increases enrollment by an average of 12.6 percentage points, a very large increase.

In summary, both the basic and savings treatments generate significant attendance effects for all students, but they appear particularly effective among those with the lowest probability of attending absent the treatment. When it comes to enrollment, though, the savings treatment generates larger gains than the basic treatment for all students, but these gains are much larger

\footnotetext{
${ }^{22}$ While there appear to be differences in both the level of the treatment effect and the slope in projected attendance, the differences are not statistically significant at conventional levels. The p-value on a test of equality of the level effects is 0.498 while the p-value on a test of equality of the slopes is 0.51 .
} 
for the students with the lowest probability of enrollment absent the treatment. Hence it appears that a conditional cash transfer program that combines incentives for good attendance with help saving for the following year is an especially effective strategy for increasing enrollment for the poorest and most at risk students.

Analysis of the tertiary treatment is partially constrained by the smaller sample size. However, the effects on subsamples of the students seem to be similar to that of the savings treatment. In results not presented in this draft, we estimated equations similar to those in Table 5 for the tertiary treatment. The tertiary treatment exhibited the same relative effect on girls' attendance rates as the basic and savings treatment. We found no statistically significant differences in the effects of the program by income, but we did find differential effects by the projected student participation rates. Figures 3 and 4 provide the same estimates as Figures 1 and 2 - a non-parametric regression of the estimated attendance and enrollment rates on the projected measures. In both cases, the tertiary treatment has a significantly larger effect on the most academically at-risk students. In a specification similar to the one in Table 5, columns 5 and 6, the enrollment effect is statistically significant at the one percent level with a 2.2 percentage point larger treatment effect for each 10 percentage points less likely a child would have been to attend without the program. The effect on attendance is not statistically significant in this specification.

\section{Survey-Based Outcomes}

We present three pieces of information from the follow-up survey data. First, we replicate the attendance and enrollment outcomes using the self-reported information provided by families. Second, for students who were already in their final year of secondary school at baseline (grade 
11), we compare the treatments' efficacy in encouraging graduation and matriculation to tertiary institutions. Finally, we report the effects of the program on labor market activities. ${ }^{23}$

\section{A. Self-Reported Attendance and Enrollment}

In addition to the monitored attendance and administrative enrollment data we described above, we also asked students to self-report their attendance and enrollment in 2006. These questions were asked in a standard format. For enrollment we asked "Currently, does this person attend school or a university", and for attendance we asked "How many days did you miss school in the last two weeks?". ${ }^{24}$ Given that we are confident in the accuracy of the monitored and administrative data, this offers an opportunity to assess the quality of this type of self reported data. This question is particularly important in the context of conditional cash transfer programs because, given the nature of the intervention, families know that the program is designed to generate higher levels of participation. This combined with the possible, although erroneous, fear that their responses may affect their receipt of the stipends may encourage not just overreporting of participation, but differentially higher over-reporting by the groups exposed to the treatments.

The results using the self-reported information are provided in Table 6. All estimates are generated using Equation (2). Results for self-reported attendance are provided in columns 1 through 3 and the results for self-reported enrollment are presented in the last three columns. Within each group, the first column provides an estimate for the basic-savings experiment, the

\footnotetext{
${ }^{23}$ As described in Section III.C, overall attrition rate on the follow-up survey was extremely low (less than 2 percent across all experimental groups). In the Appendix, we also (a.) compare the subsample of students from the 68 schools identified for surveying to those we omitted and (b.) compare individuals identified for surveying across research groups. No significant differences were found across any comparison.

${ }^{24}$ Slight care must be taken in comparing these results to the monitored attendance data because they relate to different years - the monitored data relates to 2005 while the self-reported data is for 2006 . However, given the nature of the results, this is unlikely to be the source of the discrepancy.
} 
second for the tertiary experiment, and the final column pools the data from grades nine and ten from both experiments. Effectively, these estimates reproduce the estimates in columns 3, 6, and 7 in Tables 3 and 4 with the self-reported measures.

For every estimated treatment effect, the results are significantly smaller than what was estimated using the monitored and administrative data. Only two of the estimates are statistically significant - the tertiary treatment for attendance in column 3 and the savings treatment for column 6, but the latter is actually negative. The results suggest that, rather than overstating the observed treatment effect, the self-reported estimates actually significantly understate the effect. The challenge seems to be that both the treatment and control groups are subject to significant positive bias in their reported participation rates, and because the rates are capped at 100 percent, the difference between the groups is compressed. For example, in the basic-savings experiment, the attendance rates in the self-reported data are 95 percent but only 79 percent in the monitored data. In the same experiment, students report re-enrollment at rates of 98 percent but the administrative data suggests that the real rate is only 74 percent.

These results suggest that self-reported measures may bias the observed treatment effects downwards. That said, this is the first study that, to our knowledge, has yielded such uniformly high self-reported participation rates. It does suggest that monitored data, though expensive, may be the best strategy for assessing participation levels. At the very least, this suggests that one needs to be particularly careful in interpreting estimates based on self-reported results. 


\section{B. Graduation and Tertiary Enrollment}

Keeping in mind the caveats from the previous section, we analyze the effects of each intervention on self-reported graduation and tertiary enrollment ${ }^{25}$ for students who were in their last year of secondary school at the start of the study (grade 11).

The results are presented in Table 7. All estimates are based on Equation (2). The layout of the table is identical to that of Table 6, except that the first three columns focus on graduation and the second three on tertiary enrollment. All the estimated treatment effects on graduation are positive. For the savings and tertiary treatments, the magnitudes are similar to the administrative enrollment effects observed in Table 4; for the basic treatment, though, we observe larger magnitudes here than in Table 4. That said, none of these effects are statistically significant, most likely because sample sizes are significantly smaller than in prior tables. If we pool the treatments, the overall average treatment effect is 4.0 percentage points and it is statistically significant at the ten percent level (p-value 0.09).

The effects on tertiary enrollment, however, are both positive and statistically significant for the savings and tertiary treatments. Recall that the tertiary treatment specifically incentivized enrollment in tertiary institutions both by providing a substantial transfer to students in the year after they graduated and by making the payment sooner if they students could document enrollment. The savings treatment, on the other hand, did not have any direct relationship with tertiary enrollment but did provide the families of students a transfer at the time that students would normally have to register. Looking first at the basic-savings experiment in column 4, the savings treatment increased tertiary enrollment by 9.4 percentage points (statistically significant at the 5 percent level) while the effect of the basic treatment is also positive but statistically

\footnotetext{
${ }^{25}$ Given the data available to us, we cannot break down the type of institution, but discussions with the program
} staff indicate that students largely enrolled in vocational education programs. 
insignificant. While the difference in the magnitude of effects is larger than the difference observed in Table 4 for administrative enrollment, the difference is not statistically significant (p-value is 0.19). The effect we estimate for the tertiary treatment is extremely large, an increase of 48.9 percentage points, and statistically significantly different from the effect of the basic treatment (p-value $<0.001)$.

Given the extremely large effect observed for the tertiary treatment and the self-reporting issues we discussed in the previous section, it is reasonable to ask whether these tertiary enrollment findings are credible. In particular, are students in the savings and tertiary treatment groups lying about being enrolled in tertiary institutions? At first glance, the savings treatment effect appears much more believable. It is of the same order of magnitude as the administrative enrollment effect in Table 4. Plus, because the timing of transfers under the savings treatment are not described to families as being conditional on enrolling in a tertiary institution, families should not have experienced pressure to misreport enrollment, even if they misunderstood the surveyors' instructions. ${ }^{26}$

For the tertiary treatment, though, it is more difficult to rule out the possibility that the treated students gave surveyors the answer that they thought was desired. Yet, if families in the tertiary treatment group are lying, they seem to do so very consistently throughout the follow-up survey. Indeed, the observed rate of tertiary enrollment increases to three times the control average of 18.9 percentage points; in Table 8 below, we will see a similar tripling in the fraction of children whose primary activity is reported to be studying. In addition, the self-reported graduation rates (a pre-requisite for tertiary enrollment) seem to match the estimates based on the administrative enrollment data and verified attendance data. First, the levels reported by families

\footnotetext{
${ }^{26}$ Families were informed, before starting the survey, that their answers would not affect their participation in the program and that the data would not be provided to the SED.
} 
are consistent with the administrative data. The administrative enrollment rates for students completing the baseline survey in grades 9 and 10 is 85 percent for both experiments and it increases by grade. These rates would be consistent with the reported graduation rates of 87 and 90 percent amongst grade 11 students. Also, the estimated treatment effects for self-reported enrollment are in line with those estimated for administrative enrollment and verified attendance.

\section{Labor Market Activity}

In the follow-up survey, we also collected information on labor market outcomes, which we present in Table 8. Since students initially in grade 11 should have finished school by the time the survey was conducted, we isolate grade 11 in Panel B and pool the earlier grades in Panel A. In columns 1 and 4, we report control group averages for each experiment; columns 2, 3, and 5 contain the estimated effect for the respective treatment, using Equation (2). The first three rows in each Panel indicate the primary activity of the child (studying, work, or taking care of the household) while the last two rows show the number of hours worked in the last week that the child worked and the amount of money earned during that week (in 1,000's of pesos).

For those in the earlier grades at the time of registration, there is not much of a change in self-reported primary activities, but there is a relatively large, consistent decrease in the number of hours worked among treated children. The basic and savings treatments reduce the amount worked by about a third while the tertiary treatment has a much larger effect, reducing hours worked by more than a half or 0.8 hours in the last week worked. Earnings are less precisely estimated, but show the same pattern of results.

Turning to Panel B, we observe no detectable effects on labor market activities in the basic-savings experiment for students initially in grade 11. In contrast, and consistent with the 
very large tertiary enrollment effects reported in Table 7, the tertiary treatment appears to shift students away from labor market work and towards educational institutions. Forty-three percent more students report that their primary activity is studying (a tripling consistent with the tripling in tertiary enrollment reported in Table 7), and these students seem equally drawn from those who would have otherwise been working or helping around the house. On average, students work 7.3 hours less a week and earn 12,000 pesos less.

\section{Sibling Effects}

Having a child enrolled in a CCT program may affect outcomes for his or her siblings. On the one hand, the additional resources brought in by the CCT program may improve educational opportunities for his or her siblings as families spread these new resources across children; on the other hand, if some children are preferred, the receipt of a CCT by these children could reinforce those preferences, resulting in resources being less equally distributed than before. While we do not have sufficient data to fully unpack the decision process within the family, the intra-family variation in treatment assignment does provide a reduced form test of whether receiving the transfer changes the allocation of educational opportunities within the household.

The first decision that families faced was whether to enroll a child in the lottery. Surprisingly, not all eligible children were enrolled, suggesting that families may have preferences about which children to educate. On average, the 6,619 families who completed a follow-up survey had 2.5 kids in the appropriate age range to enroll in the lottery, but only enrolled 1.3 children. Looking only at the responses of families who ended up in the control group, 93 percent of the children registered for the lottery reportedly attend school at the time of the follow-up survey, compared with only 75 percent of the children that were also eligible but 
were not registered. This is despite the significant over-reporting of enrollment rates observed in the previous section. Similarly, registered children work 3.1 hours less a week (1.4 hours versus 4.6 hours in the last week worked) than eligible but non-registered children. Hence, this suggests that even absent the CCT, families do not treat all their children equally. This also implies that in order to study causal spillovers of program participation by one child on non-participating siblings, we need to restrict ourselves to the subset of siblings that were also registered.

Unfortunately, most families $(5,132)$ only registered one child, and very few registered more than two (158). We focus in Table 9 on families who registered two children, providing a sample of 1,926 students, 1,771 with available administrative enrollment data. We also restrict ourselves to using our two preferred outcomes - monitored attendance and administrative enrollment - and only rely on the surveys to map the children’s sibling relationships. All results are estimated using a specification similar to Equation (2). Due to the small sample size, we pool the treatments rather than analyze them individually.

Columns 1 and 2 of Table 9 contain comparisons of untreated children with and without treated siblings using the monitored attendance and administrative enrollment data respectively. On average, untreated children with treated siblings have lower participation rates than untreated children whose siblings are also untreated. Attendance is lower by 3 percentage points and enrollment is 7.3 percentage points lower. The next four columns further break the comparison down by gender - first estimating the effect for untreated girls in columns 3 and 4 and then for untreated boys in columns 5 and 6 . The effect is qualitatively similar for both genders, though the magnitude is stronger and only statistically significant at conventional levels for girls.

All in all, untreated children appear if anything to see their educational outcomes deteriorate if one of their siblings becomes a CCT recipient. This is inconsistent with the view 
that the additional household resources generated by the CCT program are used to invest in the education of the untreated children; in fact, families with a treated child appear to take some educational inputs (resources, monitoring, etc) away from the untreated children.

The estimates presented in columns 7-10 further support this interpretation. Columns 7 and 8 compare the participation rates of untreated children to their treated siblings in households that received only one treatment. As expected, the treated siblings have higher participation rates, though the effect is only significant for enrollment. Columns 9 and 10 compare treated children with untreated siblings to treated children who also have treated siblings. Unlike what one would expect if resources were equalized, the treated children with untreated siblings perform just as well as the treated children with treated siblings.

\section{Conclusion}

This project demonstrates that experimenting with the design of incentive programs may have substantial benefits in terms of the efficacy of these programs. For the education programs we evaluate, simply postponing some of the cash transfers to a large lump-sum, paid at the time when the re-enrollment decision is made (and re-enrollment expenses incurred), increases enrollment in both secondary and tertiary institutions without reducing daily attendance. This is particularly true for the poorest students and those most at-risk of dropping out. This suggests that there is much to gain in designing CCTs that better take into account the financial challenges many families may face, such as difficulties saving money, in addition to the more common focus on short-term liquidity constraints.

Also, incentivizing on graduation rather than just attendance is shown to be particularly effective, leading to higher levels of daily attendance and higher levels of enrollment at the 
secondary and tertiary levels. The results indicate that the specific behaviors cash transfers are conditioned on should be chosen more carefully.

Another important dimension in the design of educational incentive programs is deciding on eligibility rules. In this regard, our intriguing results regarding within-family dynamics suggest that eligibility rules that cut across children rather than just across families (for example, restricting eligibility to certain age groups rather than to certain household income groups) may have unintended consequences. In particular, we find that children that registered for the program but were not selected for treatment end up attending school less if one of their siblings was treated than if that sibling was also untreated. This suggests that families might redirect some of their prior educational investments away from program-ineligible children, leading to increased inequality in educational attainment within the household. Of course, the treatments increase the overall resources available to families, and we cannot rule out future transfers from educated to non-educated siblings that would more equally distribute the welfare gains. However, this result, which is strongest for girls, unambiguously suggests that the ways in which families mediate the allocation of educational opportunities should be an important area for future research. 


\section{References}

Angelucci, M. G. DeGiorgi, M. A. Rangel, and I. Rasul. (2009) "Family Networks and School Enrolment: Evidence from a Randomized Social Experiment” NBER Working Paper No. 14949

Angrist, J. D., E. Bettinger, E. Bloom, E. M. King and M. Kremer. (2002) “Vouchers for Private Schooling in Colombia: Evidence from a Randomized Natural Experiment,” American Economic Review 92: 1535-59

Angrist, Joshua D., Eric Bettinger, and Michael Kremer. (2006) “Long-Term Educational Consequences of Secondary School Vouchers: Evidence from Administrative Records in Colombia.” American Economic Review 96:847-862.

Ashraf, Nava, Dean Karlan, and Wesley Yin. (2006) “Tying Odysseus to the Mast: Evidence from a Commitment Savings Product in the Phillipines,” Quarterly Journal of Economics, 121(2): 635-672.

Attanasio, Orazio, Erich Battistin, Emla Fitzsimons, Alice Mesnard and Marcos VeraHernández. (2005). “How Effective are Conditional Cash Transfers?: Evidence from Colombia.” The Institute of Fiscal Studies Briefing Note No. 54.

Attanasio, Orazio, Emla Fitzsimmons and Ana Gomez. (2005). “The Impact of a Conditional Education Subsidy on School Enrollment in Colombia.” The Institute of Fiscal Studies, Report Summary Familias 01.

Banerjee, A., S. Cole, E. Duflo and L. Linden. (2007) "Remedying Education: Evidence from Two Randomized Experiments in India," Forthcoming Quarterly Journal of Economics. 
Behrman, Jere R., Pilali Sengupta and Petra Todd. (2005). "Progressing Through PROGRESA:

An Impact Assessment of a School Subsidy Experiment in Mexico." Economic Development and Cultural Change. 54(1): 237-275.

Barrera-Osorio, Felipe, Leigh L. Linden, Miguel Urquiola. (2007) “The Effects of User Fee Reductions on Enrollment: Evidence form a Quasi-Experiment,” Columbia University Department of Economics Mimeo.

Blundell, Richard, Pierre-Andre Chiappori, and Costas Meghir. (2005) "Collective Labor Supply With Children," Journal of Political Economy, 113(6): 1277-1306

Cardoso, Eliana and André Portela Souza. (2004). “The Impact of Cash Transfers on Child Labor and School Attendance in Brazil.” Vanderbilt University Working Paper No. 04-W07.

Duflo, Esther. (2001) "Schooling and Labor Market Consequences of School Construction in Indonesia: Evidence from and Unusual Policy Experiment,” American Economic Review. 91(4): 795-813.

Duflo, Esther, Michael Kremer, and Jonathan Robinson. (2006), “Why don’t Farmers Use Fertilizers? Evidence from Field Experiments in Western Kenya.” Mimeo, MIT, Department of Economics.

Fedesarrollo. (2005) “Projecto Piloto, Subsidios Condicionados a Asistencia Escolar en Bogota: Diseño del Piloto y la Evaluación de Impacto (Informe Final)” Mimeo, Fedesarrollo, Bogota, Colombia.

Ferreira, F. H., D. Filmer, and N. Schady. (2009). "Own and sibling effects of conditional cash transfer programs : theory and evidence from Cambodia," Policy Research Working Paper Series 5001, The World Bank. 
Filmer, Deon and Norbert Schady (2006). "Getting Girls into School: Evidence from a Scholarship Program in Cambodia.” World Bank Policy Research Working Paper 3910.

Gertler, Paul. (2004). “Do Conditional Cash Transfers Improve Child Health? Evidence from PROGRESA’s Control Randomized Experiment,” American Economic Review: Papers and Proceedings. 94(2): 336-341.

Glewwe, Paul and Pedro Olinto (2004). "Evaluating the Impact of Conditional Cash Transfers on Schooling: An Experimental Analysis of Honduras PRAF Program. Final Report for USAID.” International Food Policy Research Institute.

He, F., L. Linden and M. MacLeod. (2007) "Teaching What Teachers Don't Know: An Assessment of the Pratham English Language Program" Columbia University Department of Economics Mimeo.

Kremer, Michael, Edward Miguel and Rebecca Thornton. (2007) "Incentives to Learn,” Manuscript. University of California at Berkeley, Department of Economics.

Krueger, A. and M. Lindahl. (2001). “Education for Growth: Why and For Whom?” Journal of Economic Literature, Vol. 39, No. 4, 1101-1136.

Levy, Dan and Jim Ohls. (2006). "Evaluation of Jamaica’s Path Program: Final Report.” Mathematica.

Miguel, Edward and Michael Kremer. (2004) "Worms: Identifying Impacts on Education and Health in the Presence of Treatment Externalities,” Econometrica. 72(1): 159-217. Muralidharan, Kartik and Venkatesh Sundararaman. (2006) “Teacher Incentives in Developing Countries: Experimental Evidence from India,” Working Paper. Harvard University Department of Economics. 
Oster, Emily. (2007) “Does Increased Access Increase Equality? Gender and Child Health Investments in India.” Working Paper. University of Chicago, Department of Economics.

Pitt, Mark, Shahidur Khandker and Nubuhiko Fuwa (2003). “Subsidy to Promote Girls’ Education: The Female Stipend Program in Bangladesh.” Mimeo.

Pritchett, L. (2004). “Towards A New Consensus for Addressing the Global Challenge of the Lack of Education” Copenhagen Consensus Challenge Paper in Education.

Schady, Norbert and Maria Caridad Araujo (2006). "Cash Transfers, Conditions, School Enrollment, and Child Work: Evidence from a Randomized Experiment in Ecuador.” World Bank Policy Research Working Paper 3930.

Schultz, T. Paul. (2004) "School Subsidies for the Poor: Evaluating the Mexican Progresa Poverty Program”, Journal of Development Economics, 74(1):199-250

United Nations. (2006) Deevelopment Goals Report 2006, United Nations, New York. Vélez, C.E., E. Castaño and R. Deutch. (1999) “An Economic Interpretation of Colombia’s SISBEN: A Composite Welfare Index Derived from the Optimal Scaling Algorithm” Mimeo, Poverty and Inequality Advisory Unit, Inter American Development Bank, Washington D.C. Vermeersch, Christel and Michael Kremer. (2004) "School Meals, Educational Achievement, and School Competition: Evidence from a Randomized Evaluation” World Bank Policy Research Working Paper: No. 3523, 2005.

Villatoro, Pablo (2005). “Conditional Cash Transfer Programs: Experiences from Latin America.” CEPAL Review 86: 83-96.

World Bank (2006). World Development Indicators 200, The World Bank, Washington. 
Figure 1: Monitored Attendance by Predicted Attendance Basic-Savings Experiment

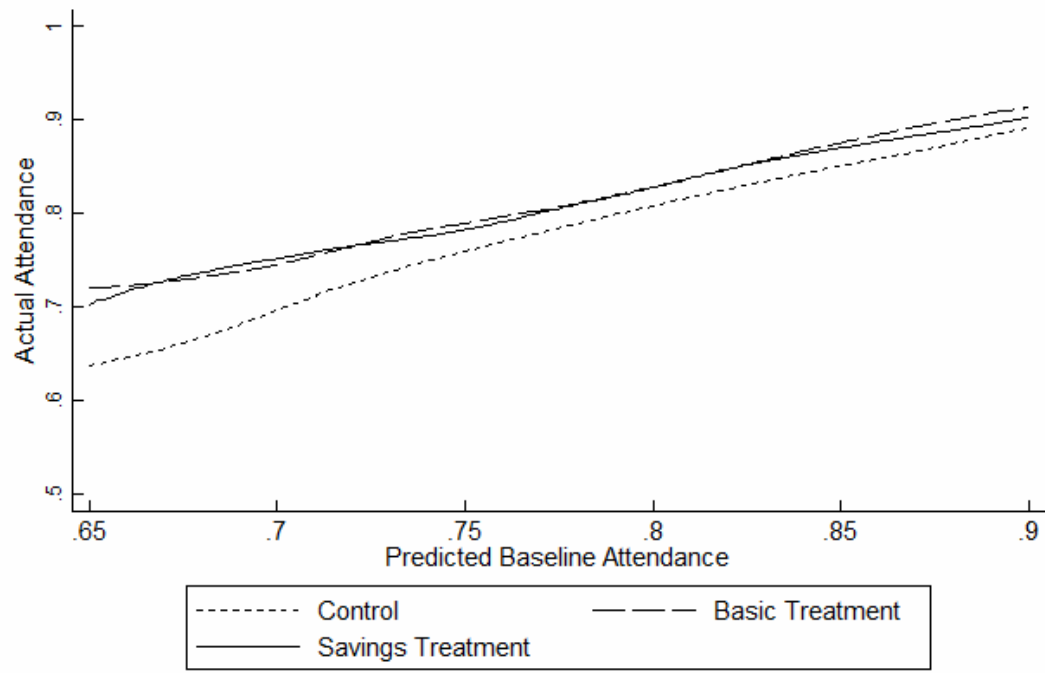

Note: Results from local polynomial regressions (bandwidth $=0.075$ )

Figure 3: Monitored Attendance by Predicted Attendance, Tertiary Experiment

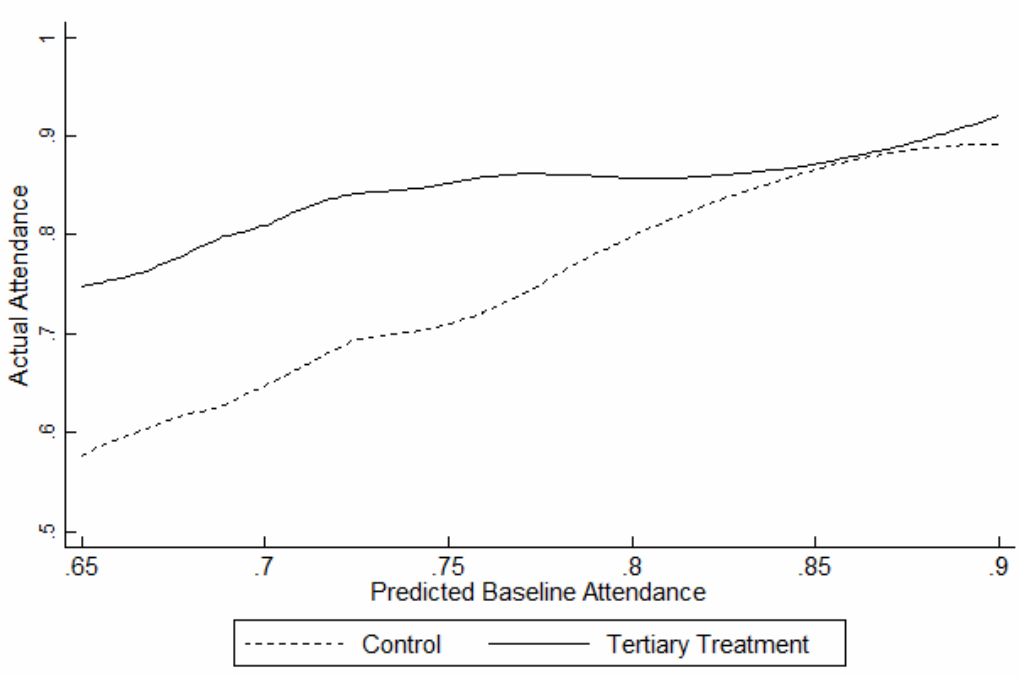

Note: Results from local polynomial regressions (bandwidth $=0.075$ )
Figure 2: Administrative Enrollment by Predicted Enrollment Basic-Savings Experiment

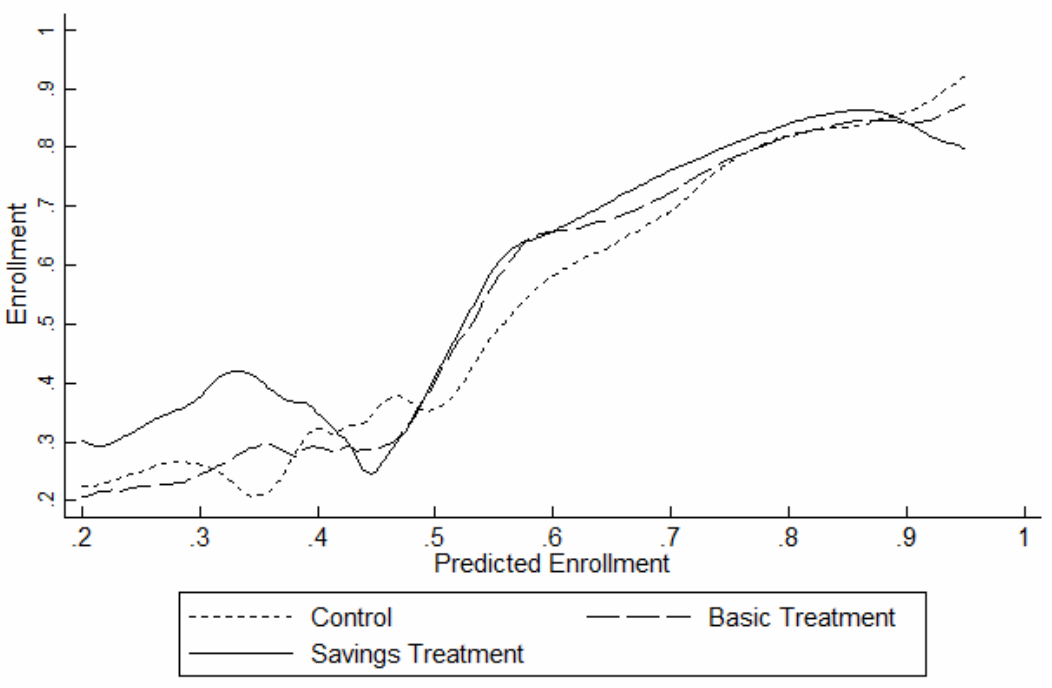

Note: Results from local polynomial regressions (bandwidth $=0.075$ )

Figure 4: Administrative Enrollment by Predicted Enrollment, Tertiary Experiment

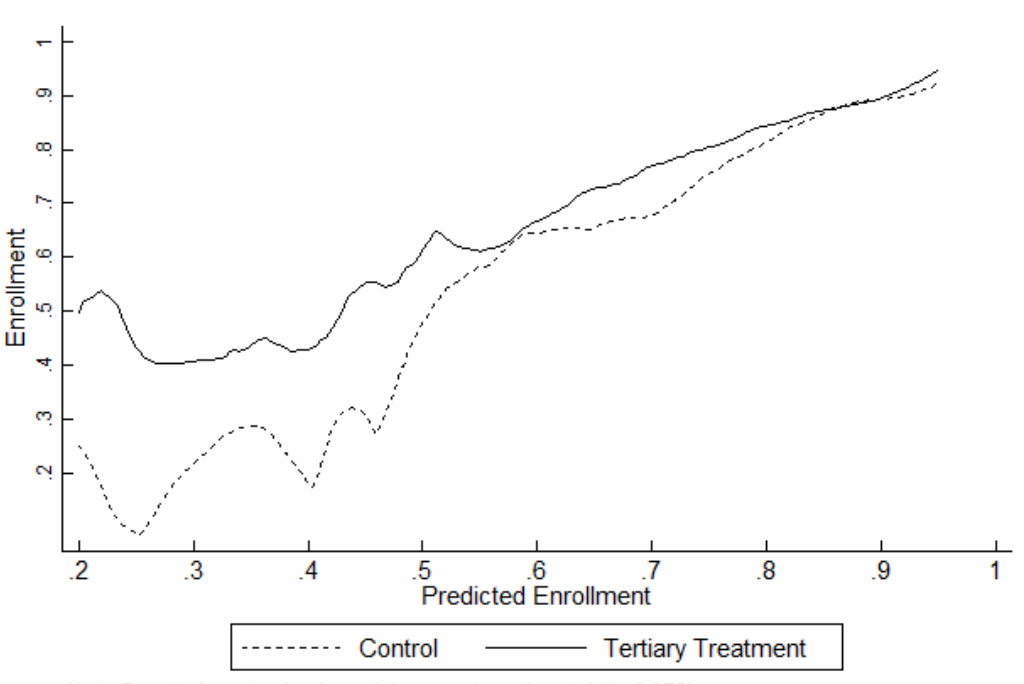

Note: Results from local polynomial regressions (bandwidth $=0.075$ ) 


\begin{tabular}{lccccccc} 
& \multicolumn{3}{c}{ Basic-Savings } & & \multicolumn{2}{c}{ Tertiary } & \\
& Control & Basic & Savings & & Control & Tertiary & Total \\
\hline $\begin{array}{l}\text { Panel A: All Registrants } \\
\text { Grades 6 - 8 }\end{array}$ & 2,439 & 2,062 & 2,059 & & 0 & 0 & $\mathbf{6 , 5 6 0}$ \\
Grades 9 - 10 & 1,243 & 1,051 & 1,051 & 1,046 & 851 & $\mathbf{5 , 2 4 2}$ \\
Grade 11 & 374 & 314 & 314 & 347 & 282 & $\mathbf{1 , 6 3 1}$ \\
Female & 1,986 & 1,681 & 1,680 & 616 & 502 & $\mathbf{6 , 4 6 5}$ \\
Male & 2,070 & 1,746 & 1,744 & 777 & 631 & $\mathbf{6 , 9 6 8}$ \\
Total Students & $\mathbf{4 , 0 5 6}$ & $\mathbf{3 , 4 2 7}$ & $\mathbf{3 , 4 2 4}$ & $\mathbf{1 , 3 9 3}$ & $\mathbf{1 , 1 3 3}$ & $\mathbf{1 3 , 4 3 3}$
\end{tabular}

Panel B: All Registrants in Schools Selected for Attendance Monitoring and Surveying

$\begin{array}{lcccccc}\text { Grades } \mathbf{6 ~ - ~ 8} & 1,362 & 1,232 & 1,198 & 0 & 0 & \mathbf{3 , 7 9 2} \\ \text { Grades 9 - 10 } & 734 & 663 & 610 & 503 & 427 & \mathbf{2 , 9 3 7} \\ \text { Grade 11 } & 197 & 177 & 169 & 166 & 131 & \mathbf{8 4 0} \\ \text { Female } & 1,108 & 1,016 & 954 & 278 & 230 & \mathbf{3 , 5 8 6} \\ \text { Male } & 1,185 & 1,056 & 1,023 & 391 & 328 & \mathbf{3 , 9 8 3} \\ \text { Total Students } & \mathbf{2 , 2 9 3} & \mathbf{2 , 0 7 2} & \mathbf{1 , 9 7 7} & \mathbf{6 6 9} & \mathbf{5 5 8} & \mathbf{7 , 5 6 9}\end{array}$

Panel C: All Registrants in Selected Schools and Covered in Baseline Survey

\begin{tabular}{lcccccc} 
Grades 6 - 8 & 1,189 & 1,215 & 1,166 & 0 & 0 & $\mathbf{3 , 5 7 0}$ \\
Grades 9 - 10 & 643 & 633 & 586 & 449 & 425 & $\mathbf{2 , 7 3 6}$ \\
Grade 11 & 179 & 188 & 177 & 160 & 148 & $\mathbf{8 5 2}$ \\
Female & 964 & 1,014 & 929 & 248 & 237 & $\mathbf{3 , 3 9 2}$ \\
Male & 1,047 & 1,022 & 1,000 & 361 & 336 & $\mathbf{3 , 7 6 6}$ \\
Total Students & $\mathbf{2 , 0 1 1}$ & $\mathbf{2 , 0 3 6}$ & $\mathbf{1 , 9 2 9}$ & $\mathbf{6 0 9}$ & $\mathbf{5 7 3}$ & $\mathbf{7 , 1 5 8}$ \\
\hline
\end{tabular}

Note: This table displays the distribution of subjects within the various research groups. Panel A contains all students in the study. Panel B contains those students in the schools that were chosen for attendance monitoring and surveying. This includes the 68 schools with the greatest number of students registered for the lottery. Of the students in the selected schools, Panel C contains the students that were captured in the baseline survey. See Table A2 for a comparison of students found in the baseline to those that were not. 
Table 2: Comparison of Students Registered for the Lottery

\begin{tabular}{|c|c|c|c|c|c|c|}
\hline \multirow[b]{2}{*}{ Demographic Variable } & \multicolumn{4}{|c|}{ Basic-Savings } & \multicolumn{2}{|c|}{ Tertiary } \\
\hline & $\begin{array}{c}\text { Control } \\
\text { Average } \\
\end{array}$ & $\begin{array}{l}\text { Basic- } \\
\text { Control }\end{array}$ & $\begin{array}{c}\text { Savings- } \\
\text { Control }\end{array}$ & $\begin{array}{c}\text { Basic- } \\
\text { Savings } \\
\end{array}$ & $\begin{array}{c}\text { Control } \\
\text { Average } \\
\end{array}$ & $\begin{array}{l}\text { Tertiary- } \\
\text { Control } \\
\end{array}$ \\
\hline \multicolumn{7}{|c|}{ Panel A: Indexes of Household Assets } \\
\hline Possessions & $\begin{array}{c}1.9 \\
(1.10)\end{array}$ & $\begin{array}{l}0.07^{\star \star \star} \\
(0.02)\end{array}$ & $\begin{array}{c}0.04 \\
(0.02)\end{array}$ & $\begin{array}{c}0.03 \\
(0.02)\end{array}$ & $\begin{array}{c}1.94 \\
(1.02)\end{array}$ & $\begin{array}{l}-0.05 \\
(0.04)\end{array}$ \\
\hline Utilities & $\begin{array}{c}4.65 \\
(1.42)\end{array}$ & $\begin{array}{r}-0.02 \\
(0.03)\end{array}$ & $\begin{array}{l}0.06^{\star *} \\
(0.03)\end{array}$ & $\begin{array}{l}-0.08^{\star \star} \\
(0.03)\end{array}$ & $\begin{array}{c}4.85 \\
(1.32)\end{array}$ & $\begin{array}{c}0.04 \\
(0.04)\end{array}$ \\
\hline Durable Goods & $\begin{array}{c}1.37 \\
(0.89)\end{array}$ & $\begin{array}{c}-0.02 \\
(0.02)\end{array}$ & $\begin{array}{c}0.01 \\
(0.02)\end{array}$ & $\begin{array}{l}-0.03 \\
(0.02)\end{array}$ & $\begin{array}{r}1.63 \\
(0.86)\end{array}$ & $\begin{array}{r}0.02 \\
(0.03)\end{array}$ \\
\hline Physical Infrastructure & $\begin{array}{l}11.65 \\
(1.75)\end{array}$ & $\begin{array}{l}-0.05 \\
(0.03)\end{array}$ & $\begin{array}{c}0.04 \\
(0.03)\end{array}$ & $\begin{array}{l}-0.09^{\star *} \\
(0.04)\end{array}$ & $\begin{array}{l}12.14 \\
(1.49)\end{array}$ & $\begin{array}{l}-0.05 \\
(0.06)\end{array}$ \\
\hline \multicolumn{7}{|c|}{ Panel B: Individual Characteristics } \\
\hline Age & $\begin{array}{l}14.38 \\
(5.30)\end{array}$ & $\begin{array}{c}0.09 \\
(0.10)\end{array}$ & $\begin{array}{l}-0.06 \\
(0.14)\end{array}$ & $\begin{array}{c}0.16 \\
(0.17)\end{array}$ & $\begin{array}{l}15.67 \\
(4.23)\end{array}$ & $\begin{array}{l}-0.06 \\
(0.19)\end{array}$ \\
\hline Gender & $\begin{array}{c}0.5 \\
(0.50)\end{array}$ & $\begin{array}{c}0 \\
(0.01)\end{array}$ & $\begin{array}{c}0 \\
(0.01)\end{array}$ & $\begin{array}{r}0.01 \\
(0.01)\end{array}$ & $\begin{array}{r}0.45 \\
(0.50)\end{array}$ & $\begin{array}{l}-0.01 \\
(0.02)\end{array}$ \\
\hline Years of Education & $\begin{array}{c}5.61 \\
(1.86)\end{array}$ & $\begin{array}{l}-0.02 \\
(0.04)\end{array}$ & $\begin{array}{l}-0.01 \\
(0.05)\end{array}$ & $\begin{array}{c}-0.02 \\
(0.04)\end{array}$ & $\begin{array}{r}7.43 \\
(1.34)\end{array}$ & $\begin{array}{l}-0.05 \\
(0.05)\end{array}$ \\
\hline \multicolumn{7}{|c|}{ Panel C: Household Characteristics } \\
\hline Single Head & $\begin{array}{c}0.3 \\
(0.46)\end{array}$ & $\begin{array}{c}0.02^{*} \\
(0.01)\end{array}$ & $\begin{array}{c}0.01 \\
(0.01)\end{array}$ & $\begin{array}{c}0.01 \\
(0.01)\end{array}$ & $\begin{array}{c}0.27 \\
(0.44)\end{array}$ & $\begin{array}{c}0.01 \\
(0.02)\end{array}$ \\
\hline Age of Head & $\begin{array}{c}45.92 \\
(10.27)\end{array}$ & $\begin{array}{l}-0.07 \\
(0.17)\end{array}$ & $\begin{array}{c}0.11 \\
(0.23)\end{array}$ & $\begin{array}{l}-0.19 \\
(0.21)\end{array}$ & $\begin{array}{l}46.21 \\
(8.59)\end{array}$ & $\begin{array}{r}0.21 \\
(0.28)\end{array}$ \\
\hline Years of Ed, Head & $\begin{array}{c}5.65 \\
(2.94)\end{array}$ & $\begin{array}{r}-0.11 \\
(0.08)\end{array}$ & $\begin{array}{l}-0.18^{* \star *} \\
(0.07)\end{array}$ & $\begin{array}{c}0.07 \\
(0.07)\end{array}$ & $\begin{array}{c}5.94 \\
(2.94)\end{array}$ & $\begin{array}{r}-0.13 \\
(0.09)\end{array}$ \\
\hline People in Household & $\begin{array}{c}5.42 \\
(2.01)\end{array}$ & $\begin{array}{l}-0.04 \\
(0.05)\end{array}$ & $\begin{array}{l}-0.03 \\
(0.05)\end{array}$ & $\begin{array}{l}-0.02 \\
(0.04)\end{array}$ & $\begin{array}{c}5.16 \\
(1.78)\end{array}$ & $\begin{array}{l}-0.01 \\
(0.07)\end{array}$ \\
\hline Member under 18 & $\begin{array}{c}2.57 \\
(1.35)\end{array}$ & $\begin{array}{r}0.03 \\
(0.03)\end{array}$ & $\begin{array}{c}0.01 \\
(0.03)\end{array}$ & $\begin{array}{c}0.01 \\
(0.03)\end{array}$ & $\begin{array}{c}2.31 \\
(1.20)\end{array}$ & $\begin{array}{c}0.05 \\
(0.06)\end{array}$ \\
\hline \multicolumn{7}{|l|}{ Panel D: Poverty Measures } \\
\hline Estrato & $\begin{array}{c}1.44 \\
(0.83)\end{array}$ & $\begin{array}{l}-0.01 \\
(0.02)\end{array}$ & $\begin{array}{r}0.02 \\
(0.02)\end{array}$ & $\begin{array}{l}-0.03^{*} \\
(0.02)\end{array}$ & $\begin{array}{c}1.63 \\
(0.77)\end{array}$ & $\begin{array}{l}-0.01 \\
(0.03)\end{array}$ \\
\hline SISBEN Score & $\begin{array}{l}11.76 \\
(4.64)\end{array}$ & $\begin{array}{l}-0.11 \\
(0.08)\end{array}$ & $\begin{array}{l}-0.02 \\
(0.11)\end{array}$ & $\begin{array}{c}-0.1 \\
(0.10)\end{array}$ & $\begin{array}{l}13.44 \\
(4.33)\end{array}$ & $\begin{array}{r}0.03 \\
(0.17)\end{array}$ \\
\hline $\begin{array}{l}\text { Household Income } \\
\text { (1,000 Pesos) }\end{array}$ & $\begin{array}{r}366.7 \\
(241.01) \\
\end{array}$ & $\begin{array}{r}-4.73 \\
(5.77) \\
\end{array}$ & $\begin{array}{r}-0.35 \\
(6.17) \\
\end{array}$ & $\begin{array}{r}-4.37 \\
(6.64) \\
\end{array}$ & $\begin{array}{r}402.03 \\
(235.44) \\
\end{array}$ & $\begin{array}{r}3.18 \\
(8.51) \\
\end{array}$ \\
\hline
\end{tabular}

Note: This table presents a comparison of students in each of the listed research groups. Columns 1 and 5 contain the average characteristics of the respective control students while columns $2,3,4$, and 6 contain the average difference between the respective control students and treatment students. Panel A contains indices of household assets (positive values indicate wealthier families). Panel B contains individual student characteristics, and Panel $C$ contains characteristics of the students' families. Panel D contains poverty measures available in the SISBEN data set. This includes the "estrato" number which is a geographic measure of poverty as well as the SISBEN score which is a continuous score used to classify households for various social programs. Standard errors are clustered at the school level. * significant at the 10 percent level, ** at the 5 percent level, and ${ }^{\star \star *}$ at the 1 percent level. 
Table 3: Effects on Monitored School Attendance Rates

\begin{tabular}{|c|c|c|c|c|c|c|c|}
\hline & \multicolumn{3}{|c|}{ Basic-Savings } & \multicolumn{3}{|c|}{ Tertiary } & \multirow{2}{*}{$\frac{\text { Both }}{(7)}$} \\
\hline & $(1)$ & $(2)$ & (3) & (4) & $(5)$ & (6) & \\
\hline Basic Treatment & $\begin{array}{c}0.033^{\star * *} \\
(0.007)\end{array}$ & $\begin{array}{c}0.032^{\star * *} \\
(0.008)\end{array}$ & $\begin{array}{c}0.032^{\star * *} \\
(0.007)\end{array}$ & & & & $\begin{array}{l}0.025^{\star *} \\
(0.010)\end{array}$ \\
\hline Savings Treatment & $\begin{array}{c}0.029 * \star * \\
(0.008)\end{array}$ & $\begin{array}{c}0.027^{* * *} \\
(0.008)\end{array}$ & $\begin{array}{l}0.027^{\star * *} \\
(0.007)\end{array}$ & & & & $\begin{array}{l}0.028 * * \\
(0.012)\end{array}$ \\
\hline Tertiary Treatment & & & & $\begin{array}{c}0.052^{\star \star \star} \\
(0.018)\end{array}$ & $\begin{array}{c}0.054^{\star \star \star} \\
(0.016)\end{array}$ & $\begin{array}{l}0.056^{\star *} \\
(0.020)\end{array}$ & $\begin{array}{c}0.055^{\star \star *} \\
(0.020)\end{array}$ \\
\hline HO: Basic == Savings & & & & & & & \\
\hline F-Stat & 0.31 & 0.4 & 0.48 & & & & 0.05 \\
\hline $\begin{array}{c}\text { p-value } \\
\text { Ho: } \text { Tertiary }==\text { Basic }\end{array}$ & 0.58 & 0.53 & 0.49 & & & & 0.82 \\
\hline F-Stat & & & & & & & 1.87 \\
\hline p-value & & & & & & & 0.18 \\
\hline Demographic Controls & & $\mathrm{V}$ & $\sqrt{ }$ & & $\sqrt{ }$ & $\sqrt{ }$ & $\sqrt{ }$ \\
\hline School Fixed Effects & & & $\sqrt{ }$ & & & $\mathrm{v}$ & $\sqrt{ }$ \\
\hline Observations & 5799 & 5799 & 5799 & 930 & 930 & 930 & 2937 \\
\hline R-Squared & $<0.01$ & 0.04 & 0.09 & 0.01 & 0.06 & 0.27 & 0.13 \\
\hline Control Average & 0.792 & 0.792 & 0.792 & 0.776 & 0.776 & 0.776 & 0.786 \\
\hline
\end{tabular}

Note: This table displays the estimated effects of the respective treatments on students' monitored attendance rates.

Columns 1, 2, and 3 contain estimates of the effects of the basic and savings treatments in San Cristobal in grades 610. Columns 4,5 , and 6 contain estimates of the treatment effect for the tertiary treatment in Suba for grades 9 and 10. Column 7 contains estimates of the effects of all three treatments on students in grades 9 and 10 for all localities. Control variables include all variables listed in Table 2, the square of the child's age, the number of years too old a child is for his or her grade, and indicator variables for the child's marital status, the family's marital status, grade, and whether or not the child is over the average age for his or her grade. Standard errors are clustered at the school level.

* significant at the 10 percent level, ${ }^{* *}$ at the 5 percent level, and ${ }^{\star \star \star}$ at the 1 percent level. 
Table 4: Effects on Administrative Enrollment in Following Year

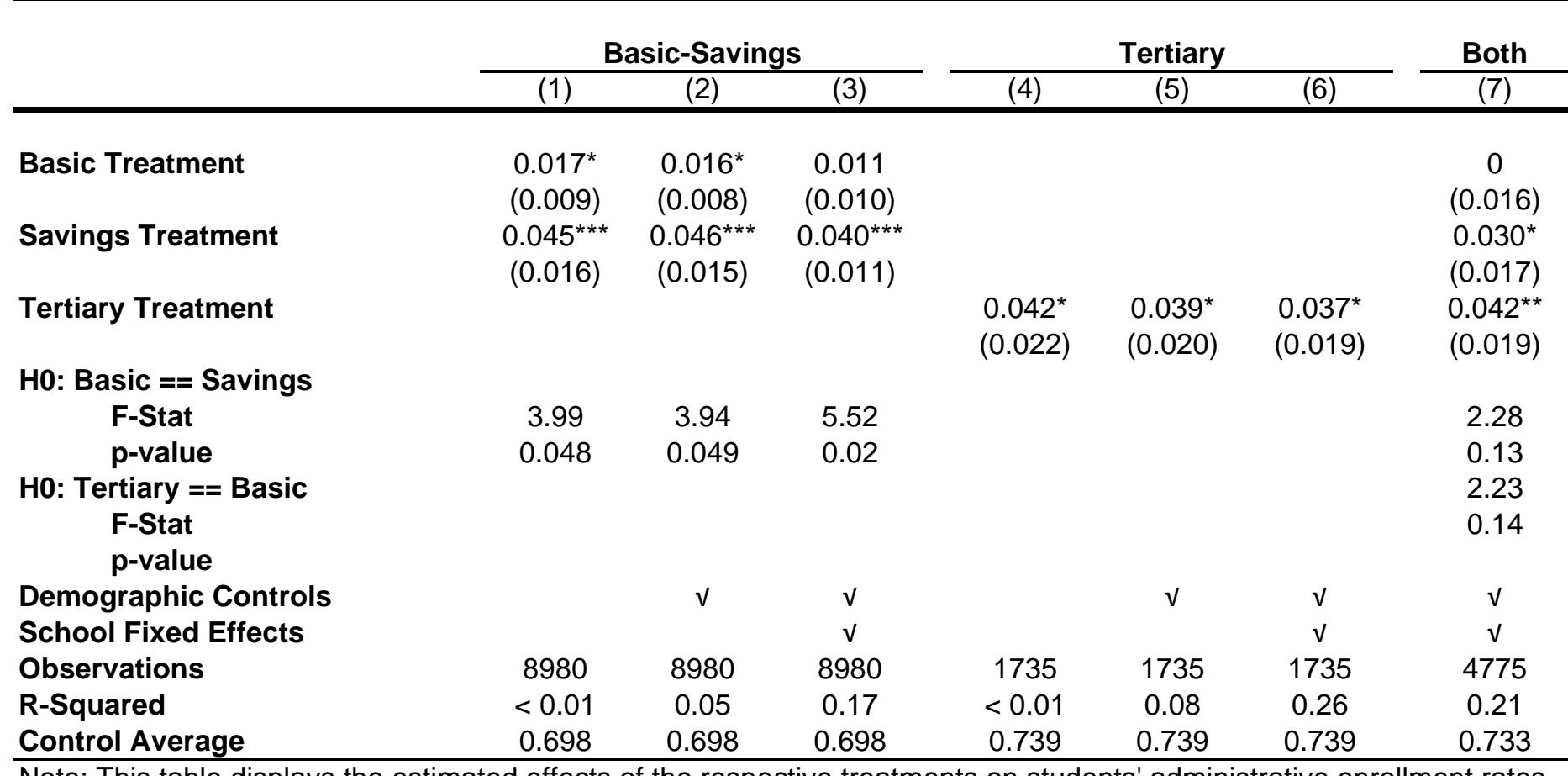

Note: This table displays the estimated effects of the respective treatments on students' administrative enrollment rates.

Columns 1, 2, and 3 contain estimates of the effects of the basic and savings treatments in San Cristobal in grades 610. Columns 4,5 , and 6 contain estimates of the treatment effect for the tertiary treatment in Suba for grades 9 and 10. Column 7 contains estimates of the effects of all three treatments on students in grades 9 and 10 for all localities. The sample includes all students registered for the lottery except for students for whom not enough information was available to match the experimental data with the administrative data. (Only 9.2 percent of students fall into this category, equally distributed across treatment groups. The results are available upon request). Control variables include all variables listed in Table 2, the square of the child's age, the number of years too old a child is for his or her grade, and indicator variables for the child's marital status, the family's marital status, grade, and whether or not the child is over the average age for his or her grade. Standard errors are clustered at the school level. * significant at the 10 percent level, ${ }^{\star *}$ at the 5 percent level, and ${ }^{\star * *}$ at the 1 percent level. 
Table 5: Variation in the Basic and Savings Treatment Effects, Basic-Savings Experiment

\begin{tabular}{|c|c|c|c|c|c|c|}
\hline & \multicolumn{2}{|c|}{ Gender } & \multicolumn{2}{|c|}{ Income } & \multicolumn{2}{|c|}{ Projected Participation } \\
\hline & $\begin{array}{c}\text { Attendance } \\
(1) \\
\end{array}$ & $\begin{array}{c}\text { Enrollment } \\
(2)\end{array}$ & $\begin{array}{c}\text { Attendance } \\
\text { (3) }\end{array}$ & $\begin{array}{c}\text { Enrollment } \\
(4)\end{array}$ & $\begin{array}{c}\text { Attendance } \\
\text { (5) }\end{array}$ & $\begin{array}{c}\text { Enrollment } \\
(6)\end{array}$ \\
\hline Basic Treatment & $\begin{array}{c}0.049^{\star \star *} \\
(0.012)\end{array}$ & $\begin{array}{c}0.016 \\
(0.014)\end{array}$ & $\begin{array}{c}0.067^{\star \star \star} \\
(0.019)\end{array}$ & $\begin{array}{l}0.031^{*} \\
(0.018)\end{array}$ & $\begin{array}{c}0.225^{\star \star \star} \\
(0.078)\end{array}$ & $\begin{array}{c}0.03 \\
(0.066)\end{array}$ \\
\hline Savings Treatment & $\begin{array}{c}0.050^{\star \star *} \\
(0.010)\end{array}$ & $\begin{array}{c}0.048^{\star \star \star} \\
(0.015)\end{array}$ & $\begin{array}{c}0.047^{\star \star \star} \\
(0.013)\end{array}$ & $\begin{array}{l}0.043^{\star *} \\
(0.017)\end{array}$ & $\begin{array}{l}0.165^{\star *} \\
(0.066)\end{array}$ & $\begin{array}{c}0.153^{\star \star \star} \\
(0.055)\end{array}$ \\
\hline Basic * Girl & $\begin{array}{l}-0.034^{\star} \\
(0.019)\end{array}$ & $\begin{array}{c}-0.011 \\
(0.019)\end{array}$ & & & & \\
\hline Savings * Girl & $\begin{array}{c}-0.045^{\star \star \star} \\
(0.013)\end{array}$ & $\begin{array}{l}-0.016 \\
(0.018)\end{array}$ & & & & \\
\hline Girl & $\begin{array}{c}0.032^{* \star *} \\
(0.011)\end{array}$ & $\begin{array}{c}0.025 \\
(0.015)\end{array}$ & & & & \\
\hline Basic * Low Income & & & $\begin{array}{c}-0.050^{\star *} \\
(0.021)\end{array}$ & $\begin{array}{l}-0.029 \\
(0.023)\end{array}$ & & \\
\hline Savings * Low Income & & & $\begin{array}{c}-0.029^{\star \star} \\
(0.013)\end{array}$ & $\begin{array}{c}-0.006 \\
(0.021)\end{array}$ & & \\
\hline Low Income & & & $\begin{array}{c}0.014 \\
(0.015)\end{array}$ & $\begin{array}{c}0.007 \\
(0.018)\end{array}$ & & \\
\hline Basic * Proj Enrollment & & & & & & $\begin{array}{l}-0.027 \\
(0.085)\end{array}$ \\
\hline Savings * Proj Enrollment & & & & & & $\begin{array}{l}-0.161^{* \star} \\
(0.074)\end{array}$ \\
\hline Basic * Proj Attendance & & & & & $\begin{array}{c}-0.244^{\star *} \\
(0.094)\end{array}$ & \\
\hline Savings * Proj Attendance & & & & & $\begin{array}{l}-0.174^{\star \star} \\
(0.078)\end{array}$ & \\
\hline Demographic Controls & $\mathrm{v}$ & $\mathrm{v}$ & $\mathrm{v}$ & $\mathrm{v}$ & $\mathrm{v}$ & $\mathrm{v}$ \\
\hline School Fixed Effects & $\mathrm{v}$ & $\mathrm{v}$ & $\mathrm{v}$ & $\mathrm{v}$ & $\mathrm{v}$ & $\mathrm{v}$ \\
\hline Observations & 5799 & 8980 & 5799 & 8980 & 5799 & 8980 \\
\hline R-Squared & 0.09 & 0.17 & 0.09 & 0.17 & 0.09 & 0.17 \\
\hline
\end{tabular}

Note: This table displays the results on variation in the treatment effects for the basic and savings treatments from Tables 3 and 4 . Columns 1 and 2 contain results from interactions with the child's gender. Columns 3 and 4 contains results from interactions with income ("low income" is defined as a family earning less than 380,000 pesos or 190 US $\$$ a month, this is the 66th percentile for income). Columns 5 and 6 contain interactions with the projected attendance and enrollment variables. Note that all estimations include the same set of control variables, but these variables are only reported if they are interacted with the treatment variables to make the table clearer. Control variables include all variables listed in Table 2, the square of the child's age, the number of years too old a child is for his or her grade, and indicator variables for the child's marital status, the family's marital status, grade, and whether or not the child is over the average age for his or her grade. Standard errors are clustered at the school level. * significant at the 10 percent level, ${ }^{* \star}$ at the 5 percent level, ${ }^{\star * \star}$ at the 1 percent level. 


\begin{tabular}{|c|c|c|c|c|c|c|}
\hline & \multicolumn{3}{|c|}{ Self-Reported Attendance } & \multicolumn{3}{|c|}{ Self-Reported Enrollment } \\
\hline & $(1)$ & $(2)$ & (3) & $(4)$ & $(5)$ & $(6)$ \\
\hline \multirow[t]{2}{*}{ Basic Treatment } & 0.006 & & -0.003 & 0.001 & & -0.004 \\
\hline & $(0.004)$ & & $(0.007)$ & $(0.003)$ & & $(0.005)$ \\
\hline \multirow[t]{2}{*}{ Savings Treatment } & 0.007 & & 0.003 & 0.001 & & $-0.012^{*}$ \\
\hline & $(0.004)$ & & $(0.008)$ & $(0.004)$ & & $(0.006)$ \\
\hline \multirow[t]{2}{*}{ Tertiary Treatment } & & 0.021 & $0.022^{*}$ & & 0.007 & 0.007 \\
\hline & & $(0.012)$ & $(0.012)$ & & $(0.005)$ & $(0.005)$ \\
\hline \multicolumn{7}{|l|}{ H0: Basic == Savings } \\
\hline F-Stat & 0.17 & & 1.41 & 0.01 & & 1.11 \\
\hline p-value & 0.68 & & 0.24 & 0.91 & & 0.30 \\
\hline \multicolumn{7}{|l|}{ HO: Tertiary == Savings } \\
\hline F-Stat & & & 3.23 & & & 2.28 \\
\hline p-value & & & 0.08 & & & 0.14 \\
\hline Demographic Controls & $\sqrt{ }$ & $\sqrt{ }$ & $\sqrt{ }$ & $\sqrt{ }$ & $\sqrt{ }$ & $\sqrt{ }$ \\
\hline School Fixed Effects & V & V & v & v & v & v \\
\hline Observations & 5239 & 860 & 2663 & 5135 & 803 & 2590 \\
\hline R-Squared & 0.03 & 0.11 & 0.05 & 0.04 & 0.06 & 0.05 \\
\hline Control Average & 0.954 & 0.941 & 0.957 & 0.982 & 0.988 & 0.988 \\
\hline Sample & Basic-Savings & Tertiary & Both & Basic-Savings & Tertiary & Both \\
\hline
\end{tabular}

Note: This table presents the results of estimates of the treatment effect for each treatment on students' self-reported attendance rates (columns 1-3) and enrollment rates (columns 4-6). Columns 1 and 4 contain only students in the basicsavings experiment. Columns 2 and 5 contain students in the tertiary experiment, and columns 3 and 6 contain students in both experiments in grades 9 and 10. All samples include only students who completed both the baseline and follow-up surveys. Control variables include all variables listed in Table 2, the square of the child's age, the number of years too old a child is for his or her grade, and indicator variables for the child's marital status, the family's marital status, grade, and whether or not the child is over the average age for his or her grade. Standard errors are clustered at the school level. * significant at the 10 percent level, ${ }^{* \star}$ at the 5 percent level, and ${ }^{* \star *}$ at the 1 percent level. 
Table 7: Effects on Graduation and Tertiary Enrollment for Students in Grade 11

\begin{tabular}{|c|c|c|c|c|c|c|}
\hline & \multicolumn{3}{|c|}{ Graduation } & \multicolumn{3}{|c|}{ Tertiary Enrollment } \\
\hline & $(1)$ & $(2)$ & (3) & (4) & $(5)$ & (6) \\
\hline Basic Treatment & $\begin{array}{c}0.039 \\
(0.042)\end{array}$ & & $\begin{array}{c}0.036 \\
(0.042)\end{array}$ & $\begin{array}{c}0.043 \\
(0.035)\end{array}$ & & $\begin{array}{c}0.048 \\
(0.033)\end{array}$ \\
\hline Savings Treatment & $\begin{array}{c}0.04 \\
(0.032)\end{array}$ & & $\begin{array}{c}0.039 \\
(0.030)\end{array}$ & $\begin{array}{l}0.094^{\star \star} \\
(0.034)\end{array}$ & & $\begin{array}{c}0.094^{\star \star \star} \\
(0.033)\end{array}$ \\
\hline Tertiary Treatment & & $\begin{array}{c}0.047 \\
(0.036)\end{array}$ & $\begin{array}{c}0.044 \\
(0.031)\end{array}$ & & $\begin{array}{c}0.489 * \star \star \\
(0.039)\end{array}$ & $\begin{array}{c}0.487^{\star \star \star} \\
(0.040)\end{array}$ \\
\hline \multicolumn{7}{|l|}{ H0: Basic == Savings } \\
\hline F-Stat & $<0.01$ & & 0.01 & 1.82 & & 1.57 \\
\hline p-value & 0.99 & & 0.94 & 0.19 & & 0.22 \\
\hline \multicolumn{7}{|l|}{ HO: Tertiary == Savings } \\
\hline F-Stat & & & 0.02 & & & 76.70 \\
\hline p-value & & & 0.88 & & & $<0.01$ \\
\hline Demographic Controls & $\mathrm{v}$ & $\mathrm{v}$ & $\mathrm{v}$ & $\mathrm{v}$ & $\mathrm{v}$ & $\mathrm{v}$ \\
\hline School Fixed Effects & $\checkmark$ & 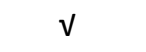 & $\checkmark$ & v & $v$ & 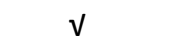 \\
\hline Observations & 529 & 297 & 826 & 513 & 290 & 803 \\
\hline R-Squared & 0.1 & 0.15 & 0.1 & 0.09 & 0.37 & 0.21 \\
\hline Control Average & 0.874 & 0.902 & 0.887 & 0.219 & 0.189 & 0.205 \\
\hline Sample & Basic-Savings & Tertiary & Both & Basic-Savings & Tertiary & Both \\
\hline \multicolumn{7}{|c|}{$\begin{array}{l}\text { Note: This table presents the results of estimates of the treatment effects on students' self-reported graduation rates (columns 1-3) } \\
\text { and tertiary enrollment rates (columns } 4-6 \text { ) for students enrolled in grade } 11 \text { at the start of the study. Columns } 1 \text { and } 4 \text { contain only } \\
\text { students in the basic-savings experiment. Columns } 2 \text { and } 5 \text { contain students in the tertiary experiment, and columns } 3 \text { and } 6 \text { contair } \\
\text { students in both experiments. All samples include only students who completed both the baseline and follow-up surveys. Control } \\
\text { variables include all variables listed in Table } 2 \text {, the square of the child's age, the number of years too old a child is for his or her } \\
\text { grade, and indicator variables for the child's marital status, the family's marital status, grade, and whether or not the child is over the } \\
\text { average age for his or her grade. Standard errors are clustered at the school level. * significant at the } 10 \text { percent level, ** at the } 5 \\
\text { percent level, and }{ }^{* \star *} \text { at the } 1 \text { percent level. }\end{array}$} \\
\hline
\end{tabular}


Table 8: Effects of Transfers on Academic Effort, Consumption, and Labor Activities

\begin{tabular}{|c|c|c|c|c|c|}
\hline \multirow[b]{2}{*}{ Outcome Variable } & \multicolumn{3}{|c|}{ Basic-Savings } & \multicolumn{2}{|c|}{ Tertiary } \\
\hline & $\begin{array}{l}\text { Control } \\
\text { Average }\end{array}$ & $\begin{array}{l}\text { Basic - } \\
\text { Control }\end{array}$ & $\begin{array}{l}\text { Savings - } \\
\text { Control }\end{array}$ & $\begin{array}{l}\text { Control } \\
\text { Average }\end{array}$ & $\begin{array}{c}\text { Tertiary - } \\
\text { Control }\end{array}$ \\
\hline \multicolumn{6}{|c|}{ Panel A: Labor Activities, Grades 6-10 } \\
\hline Primary Activity, Studying $^{\dagger}$ & $\begin{array}{c}0.936 \\
(0.006)\end{array}$ & $\begin{array}{l}-0.003 \\
(0.006)\end{array}$ & $\begin{array}{c}0.003 \\
(0.008)\end{array}$ & $\begin{array}{c}0.904 \\
(0.014)\end{array}$ & $\begin{array}{c}0.013 \\
(0.018)\end{array}$ \\
\hline Primary Activity, Work & $\begin{array}{c}0.008 \\
(0.002)\end{array}$ & $\begin{array}{l}-0.002 \\
(0.003)\end{array}$ & $\begin{array}{l}-0.001 \\
(0.003)\end{array}$ & $\begin{array}{c}0.009 \\
(0.004)\end{array}$ & $\begin{array}{l}-0.008^{*} \\
(0.005)\end{array}$ \\
\hline Primary Activity, Home & $\begin{array}{c}0.007 \\
(0.002)\end{array}$ & $\begin{array}{c}0.001 \\
(0.004)\end{array}$ & $\begin{array}{l}0.003 \\
(0.004)\end{array}$ & $\begin{array}{c}0 \\
(0.000)\end{array}$ & $\begin{array}{c}0.003 \\
(0.003)\end{array}$ \\
\hline $\begin{array}{l}\text { Hours Worked } \\
\text { Last Work Week }\end{array}$ & $\begin{array}{c}0.922 \\
(0.130)\end{array}$ & $\begin{array}{l}-0.371^{\star \star} \\
(0.160)\end{array}$ & $\begin{array}{l}-0.248^{*} \\
(0.142)\end{array}$ & $\begin{array}{c}1.5 \\
(0.311)\end{array}$ & $\begin{array}{l}-0.804^{\star \star} \\
(0.390)\end{array}$ \\
\hline $\begin{array}{l}\text { Earnings } \\
\text { Last Work Week }\end{array}$ & $\begin{array}{c}1.263 \\
(0.212)\end{array}$ & $\begin{array}{l}-0.294 \\
(0.293)\end{array}$ & $\begin{array}{l}-0.35 \\
(0.213)\end{array}$ & $\begin{array}{l}1.865 \\
(0.362)\end{array}$ & $\begin{array}{c}-0.7 \\
(0.605)\end{array}$ \\
\hline \multicolumn{6}{|c|}{ Panel B: Labor Activities, Grade 11} \\
\hline Primary Activity, Studying ${ }^{\dagger}$ & $\begin{array}{c}0.299 \\
(0.035)\end{array}$ & $\begin{array}{c}0.038 \\
(0.061)\end{array}$ & $\begin{array}{c}0.038 \\
(0.046)\end{array}$ & $\begin{array}{c}0.235 \\
(0.034)\end{array}$ & $\begin{array}{l}0.436^{\star \star \star} \\
(0.043)\end{array}$ \\
\hline Primary Activity, Work & $\begin{array}{c}0.155 \\
(0.028)\end{array}$ & $\begin{array}{l}-0.004 \\
(0.028)\end{array}$ & $\begin{array}{c}0.031 \\
(0.056)\end{array}$ & $\begin{array}{c}0.248 \\
(0.035)\end{array}$ & $\begin{array}{c}-0.153^{\star \star \star} \\
(0.051)\end{array}$ \\
\hline Primary Activity, Home & $\begin{array}{c}0.172 \\
(0.029)\end{array}$ & $\begin{array}{c}0.008 \\
(0.041)\end{array}$ & $\begin{array}{l}0.017 \\
(0.055)\end{array}$ & $\begin{array}{c}0.222 \\
(0.034)\end{array}$ & $\begin{array}{c}-0.183^{\star \star *} \\
(0.031)\end{array}$ \\
\hline $\begin{array}{l}\text { Hours Worked } \\
\text { Last Work Week }\end{array}$ & $\begin{array}{c}7.052 \\
(1.293)\end{array}$ & $\begin{array}{c}0.683 \\
(1.849)\end{array}$ & $\begin{array}{c}0.092 \\
(1.685)\end{array}$ & $\begin{array}{c}8.425 \\
(1.478)\end{array}$ & $\begin{array}{c}-7.349^{* \star \star} \\
(1.453)\end{array}$ \\
\hline $\begin{array}{l}\text { Earnings } \\
\text { Last Work Week }\end{array}$ & $\begin{array}{l}10.04 \\
(1.949)\end{array}$ & $\begin{array}{c}1.196 \\
(3.290)\end{array}$ & $\begin{array}{c}2.33 \\
(2.656)\end{array}$ & $\begin{array}{l}16.408 \\
(3.387)\end{array}$ & $\begin{array}{c}-12.089^{\star *} \\
(5.347)\end{array}$ \\
\hline
\end{tabular}

Note: This table presents the estimated treatment effects of the three treatments on labor market outcomes collected from the student follow-up survey. All regressions include both controls for student demographic characteristics as well as school level fixed effects. Control variables include all variables listed in Table 2, the square of the child's age, the number of years too old a child is for his or her grade, and indicator variables for the child's marital status, the family's marital status, grade, and whether or not the child is over the average age for his or her grade. Standard errors are clustered at the school level. * significant at the 10 percent level, ** at the 5 percent level, and * at the 10 percent level. ${ }^{\dagger}$ Percentages for each primary activity do not add to 100 percent because two categories are omitted (incapacitated, and other activities). 
Table 9: Effects of Treatment on Siblings Using Monitored and Administrative Participation, Households with Two Registered Children

Untreated Children Female Control Male Control

One Treated Child

Treated Children

Attendance Enrollment $\quad$ Attendance Enrollment

$\begin{array}{llllll}(3) & (4) & \text { (5) } & \text { (6) } & \text { (7) } & \text { (8) }\end{array}$

Attendance Enrollment

(8)

(9) (10)

\section{Sibling is Treated? (Yes or No)}

$-0.030^{*}$

$-0.073^{\star * *}$

$-0.053^{* *}$

$-0.104^{*}$

$-0.029$

$-0.054$

(0.054)

(0.031)

(0.040)

0.007

$-0.001$

Child is Treated? (Yes or No)

\section{Demographic Controls}

School Fixed Effects

Observations

\section{R-Squared}

Sample Description

\begin{tabular}{|c|c|c|c|c|c|}
\hline 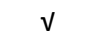 & v & V & v & V & V \\
\hline$v$ & $\checkmark$ & 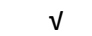 & 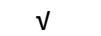 & $v$ & $\checkmark$ \\
\hline 690 & 637 & 352 & 323 & 338 & 314 \\
\hline 0.28 & 0.16 & 0.33 & 0.23 & 0.38 & 0.26 \\
\hline \multicolumn{2}{|c|}{$\begin{array}{l}\text { Untreated children in } \\
\text { households with two } \\
\text { registered children }\end{array}$} & \multicolumn{2}{|c|}{$\begin{array}{l}\text { Untreated girls in } \\
\text { households with two } \\
\text { treated children }\end{array}$} & \multicolumn{2}{|c|}{$\begin{array}{l}\text { Untreated boys in } \\
\text { households with two } \\
\text { treated children }\end{array}$} \\
\hline
\end{tabular}

$\begin{array}{cc}0.014 & 0.033^{*} \\ (0.012) & (0.018) \\ V & V \\ V & V \\ 885 & 827 \\ 0.57 & 0.17 \\ \text { Children in households } \\ \text { with one treated and one } \\ \text { untreated child }\end{array}$

(0.009)

registered children

treated children

Note: This table presents estimates of within family externalities using monitored attendance and administrative enrollment as outcomes. All estimates include only children in

households that registered two children for the lottery. Columns 1 and 2 compare children who did not receive a treatment but with treated sibling versus untreated children with untreated siblings. Columns 3 and 4 restrict the sample in columns 1 and 2 to the subset of girls, while columns 5 and 6 restrict it to the subset of boys. Columns 7 and 8 compare the participation rates of children who are treated to those who are not in households in which only one child is treated. Finally, columns 9 and 10 compare treated children whose siblings are also treated to treated children whose sibling are not treated. Family relationships are based on the student survey. Control variables include all variables listed in Table 2, the square of the child's age, the number of years too old a child is for his or her grade, and indicator variables for the child's marital status, the family's marital status, grade, and whether or not the child is over the average age for his or her grade. Standard errors are clustered at the school level. * significant at the 10 percent level, ** at the 5 percent level, and ${ }^{* \star *}$ at the 1 percent level. 


\section{Unpublished Appendix Tables}


Table A1: Comparison of Students in Schools Selected for Attendance Monitoring and Surveying

\begin{tabular}{|c|c|c|c|c|c|c|}
\hline \multirow[b]{2}{*}{ Demographic Variable } & \multicolumn{4}{|c|}{ San Cristobal } & \multicolumn{2}{|c|}{ Suba } \\
\hline & $\begin{array}{c}\text { Control } \\
\text { Average }\end{array}$ & $\begin{array}{l}\text { Basic- } \\
\text { Control }\end{array}$ & $\begin{array}{c}\text { Savings- } \\
\text { Control }\end{array}$ & $\begin{array}{c}\text { Basic- } \\
\text { Savings }\end{array}$ & $\begin{array}{c}\text { Control } \\
\text { Average } \\
\end{array}$ & $\begin{array}{l}\text { Tertiary- } \\
\text { Control }\end{array}$ \\
\hline \multicolumn{7}{|c|}{ Panel A: Indexes of Household Assets } \\
\hline Possessions & $\begin{array}{c}1.94 \\
(1.11)\end{array}$ & $\begin{array}{c}0.06^{*} \\
(0.03)\end{array}$ & $\begin{array}{l}-0.02 \\
(0.03)\end{array}$ & $\begin{array}{l}0.07^{\star \star} \\
(0.03)\end{array}$ & $\begin{array}{c}1.93 \\
(1.00)\end{array}$ & $\begin{array}{c}0.02 \\
(0.06)\end{array}$ \\
\hline Utilities & $\begin{array}{c}4.67 \\
(1.41)\end{array}$ & $\begin{array}{l}-0.03 \\
(0.05)\end{array}$ & $\begin{array}{c}0.04 \\
(0.04)\end{array}$ & $\begin{array}{l}-0.07^{*} \\
(0.04)\end{array}$ & $\begin{array}{c}4.86 \\
(1.32)\end{array}$ & $\begin{array}{c}0.11^{*} \\
(0.06)\end{array}$ \\
\hline Durable Goods & $\begin{array}{c}1.36 \\
(0.88)\end{array}$ & $\begin{array}{l}-0.03 \\
(0.03)\end{array}$ & $\begin{array}{r}0.03 \\
(0.03)\end{array}$ & $\begin{array}{l}-0.05^{*} \\
(0.03)\end{array}$ & $\begin{array}{c}1.62 \\
(0.84)\end{array}$ & $\begin{array}{c}0.06 \\
(0.05)\end{array}$ \\
\hline Physical Infrastructure & $\begin{array}{l}11.63 \\
(1.73)\end{array}$ & $\begin{array}{l}-0.09^{\star *} \\
(0.04)\end{array}$ & $\begin{array}{c}0.05 \\
(0.04)\end{array}$ & $\begin{array}{l}-0.14^{\star *} \\
(0.06)\end{array}$ & $\begin{array}{l}12.14 \\
(1.39)\end{array}$ & $\begin{array}{r}-0.02 \\
(0.08)\end{array}$ \\
\hline \multicolumn{7}{|c|}{ Panel B: Individual Characteristics } \\
\hline Age & $\begin{array}{l}14.36 \\
(5.36)\end{array}$ & $\begin{array}{c}0.08 \\
(0.11)\end{array}$ & $\begin{array}{c}-0.24 \\
(0.16)\end{array}$ & $\begin{array}{l}0.31^{* *} \\
(0.16)\end{array}$ & $\begin{array}{c}15.52 \\
(4.01)\end{array}$ & $\begin{array}{c}0.14 \\
(0.29)\end{array}$ \\
\hline Gender & $\begin{array}{c}0.49 \\
(0.50)\end{array}$ & $\begin{array}{c}0.01 \\
(0.01)\end{array}$ & $\begin{array}{r}-0.01 \\
(0.01)\end{array}$ & $\begin{array}{c}0.02 \\
(0.01)\end{array}$ & $\begin{array}{c}0.43 \\
(0.50)\end{array}$ & $\begin{array}{r}-0.01 \\
(0.03)\end{array}$ \\
\hline Years of Education & $\begin{array}{c}5.6 \\
(1.87)\end{array}$ & $\begin{array}{r}-0.08 \\
(0.05)\end{array}$ & $\begin{array}{r}-0.04 \\
(0.06)\end{array}$ & $\begin{array}{l}-0.04 \\
(0.06)\end{array}$ & $\begin{array}{c}7.42 \\
(1.24)\end{array}$ & $\begin{array}{l}-0.05 \\
(0.07)\end{array}$ \\
\hline \multicolumn{7}{|c|}{ Panel C: Household Characteristics } \\
\hline Single Head & $\begin{array}{c}0.29 \\
(0.45)\end{array}$ & $\begin{array}{c}0.01 \\
(0.01)\end{array}$ & $\begin{array}{c}0.01 \\
(0.01)\end{array}$ & $\begin{array}{c}0 \\
(0.02)\end{array}$ & $\begin{array}{c}0.26 \\
(0.44)\end{array}$ & $\begin{array}{c}0.02 \\
(0.02)\end{array}$ \\
\hline Age of Head & $\begin{array}{r}45.79 \\
(10.33)\end{array}$ & $\begin{array}{l}-0.19 \\
(0.26)\end{array}$ & $\begin{array}{c}0.23 \\
(0.32)\end{array}$ & $\begin{array}{l}-0.42 \\
(0.28)\end{array}$ & $\begin{array}{l}45.62 \\
(8.42)\end{array}$ & $\begin{array}{l}0.86^{\star \star} \\
(0.36)\end{array}$ \\
\hline Years of Ed, Head & $\begin{array}{c}5.59 \\
(2.92)\end{array}$ & $\begin{array}{l}-0.03 \\
(0.10)\end{array}$ & $\begin{array}{c}-0.1 \\
(0.09)\end{array}$ & $\begin{array}{c}0.08 \\
(0.10)\end{array}$ & $\begin{array}{r}5.83 \\
(2.99)\end{array}$ & $\begin{array}{c}-0.17 \\
(0.11)\end{array}$ \\
\hline People in Household & $\begin{array}{c}5.4 \\
(1.93)\end{array}$ & $\begin{array}{c}0.02 \\
(0.06)\end{array}$ & $\begin{array}{l}-0.01 \\
(0.06)\end{array}$ & $\begin{array}{c}0.03 \\
(0.06)\end{array}$ & $\begin{array}{c}5.13 \\
(1.61)\end{array}$ & $\begin{array}{c}0.1 \\
(0.09)\end{array}$ \\
\hline Member under 18 & $\begin{array}{c}2.59 \\
(1.33)\end{array}$ & $\begin{array}{c}0.07 \\
(0.05)\end{array}$ & $\begin{array}{c}0.02 \\
(0.04)\end{array}$ & $\begin{array}{c}0.05 \\
(0.04)\end{array}$ & $\begin{array}{c}2.36 \\
(1.17)\end{array}$ & $\begin{array}{c}0.07 \\
(0.09)\end{array}$ \\
\hline \multicolumn{7}{|l|}{ Panel D: Poverty Measures } \\
\hline Estrato & $\begin{array}{c}1.45 \\
(0.81)\end{array}$ & $\begin{array}{l}-0.01 \\
(0.03)\end{array}$ & $\begin{array}{l}-0.01 \\
(0.03)\end{array}$ & $\begin{array}{l}-0.01 \\
(0.03)\end{array}$ & $\begin{array}{c}1.65 \\
(0.76)\end{array}$ & $\begin{array}{r}0.01 \\
(0.04)\end{array}$ \\
\hline SISBEN Score & $\begin{array}{l}11.77 \\
(4.65)\end{array}$ & $\begin{array}{l}-0.21 \\
(0.13)\end{array}$ & $\begin{array}{l}-0.13 \\
(0.15)\end{array}$ & $\begin{array}{l}-0.08 \\
(0.14)\end{array}$ & $\begin{array}{l}13.51 \\
(4.26)\end{array}$ & $\begin{array}{c}0.24 \\
(0.25)\end{array}$ \\
\hline $\begin{array}{l}\text { Household Income } \\
\text { (1,000 Pesos) }\end{array}$ & $\begin{array}{r}367.54 \\
(237.31) \\
\end{array}$ & $\begin{array}{r}-5.47 \\
(7.44) \\
\end{array}$ & $\begin{array}{r}2.29 \\
(8.49) \\
\end{array}$ & $\begin{array}{r}-7.76 \\
(6.61) \\
\end{array}$ & $\begin{array}{r}396.96 \\
(223.23) \\
\end{array}$ & $\begin{array}{c}1.24 \\
(11.05) \\
\end{array}$ \\
\hline
\end{tabular}

Note: This table presents a comparison of students in the 68 schools selected for surveying for each of the listed research groups. Columns 1 and 5 contains the average characteristics of the respective control groups while columns 2, 3, 4, and 6 contain the average difference between the respective control students and treatment students. Panel A contains indices of household assets (positive values indicate wealthier families). Panel B contains individual student characteristics, and Panel C contains characteristics of the students' families. Panel D contains poverty measures available in the SISBEN data set. This includes the "estrato" number which is a geographic measure of poverty as well as the SISBEN score which is a continuous score used to classify households for various social programs. Standard errors are clustered at the school level. * significant at the 10 percent level, ** at the 5 percent level, and ${ }^{* *}$ at the 1 percent level. 
Table A2: Relative Differences Between Students Covered and not Covered in Baseline

\begin{tabular}{|c|c|c|c|c|c|c|}
\hline \multirow[b]{2}{*}{ Demographic Variable } & \multicolumn{4}{|c|}{ San Cristobal } & \multicolumn{2}{|c|}{ Suba } \\
\hline & $\begin{array}{c}\text { Control } \\
\text { Difference }\end{array}$ & $\begin{array}{l}\text { Basic- } \\
\text { Control }\end{array}$ & $\begin{array}{l}\text { Savings- } \\
\text { Control }\end{array}$ & $\begin{array}{l}\text { Basic- } \\
\text { Savings }\end{array}$ & $\begin{array}{c}\text { Control } \\
\text { Difference }\end{array}$ & $\begin{array}{l}\text { Tertiary- } \\
\text { Control }\end{array}$ \\
\hline \multicolumn{7}{|l|}{ Panel A: Attrition Rate } \\
\hline Number not Tested & 282 & 163 & 176 & & 60 & 33 \\
\hline \multirow[t]{2}{*}{ Percentage not Tested } & 0.12 & $-0.04^{\star \star \star}$ & $-0.03^{\star \star \star}$ & -0.01 & 0.09 & $-0.03^{\star \star}$ \\
\hline & $(0.33)$ & $(0.01)$ & $(0.01)$ & $(0.01)$ & $(0.29)$ & $(0.01)$ \\
\hline \multicolumn{7}{|c|}{ Panel B: Indexes of Household Assets } \\
\hline \multirow{2}{*}{ Possessions } & -0.01 & $-0.15^{\star}$ & -0.11 & -0.04 & 0.02 & 0.13 \\
\hline & $(0.07)$ & $(0.09)$ & $(0.10)$ & $(0.13)$ & $(0.14)$ & $(0.20)$ \\
\hline \multirow[t]{2}{*}{ Utilities } & 0.02 & 0 & -0.05 & 0.05 & -0.03 & 0.39 \\
\hline & $(0.09)$ & $(0.12)$ & $(0.16)$ & $(0.15)$ & $(0.18)$ & $(0.28)$ \\
\hline \multirow[t]{2}{*}{ Durable Goods } & -0.01 & 0.03 & -0.07 & 0.1 & 0.09 & -0.07 \\
\hline & $(0.06)$ & $(0.06)$ & $(0.08)$ & $(0.09)$ & $(0.11)$ & $(0.24)$ \\
\hline \multirow[t]{2}{*}{ Physical Infrastructure } & -0.04 & 0.13 & 0.26 & -0.12 & 0.29 & -0.19 \\
\hline & $(0.11)$ & $(0.18)$ & $(0.18)$ & $(0.22)$ & $(0.19)$ & $(0.38)$ \\
\hline \multicolumn{7}{|c|}{ Panel C: Individual Characteristics } \\
\hline \multirow[t]{2}{*}{ Age } & 0.05 & $0.84^{\star \star}$ & $1.34^{\star \star}$ & -0.49 & -0.26 & -0.05 \\
\hline & $(0.34)$ & $(0.43)$ & $(0.52)$ & $(0.58)$ & $(0.54)$ & $(0.44)$ \\
\hline \multirow[t]{2}{*}{ Gender } & 0.04 & -0.11 & -0.01 & -0.1 & 0.11 & -0.01 \\
\hline & $(0.03)$ & $(0.07)$ & $(0.05)$ & $(0.07)$ & $(0.07)$ & $(0.12)$ \\
\hline \multirow[t]{2}{*}{ Years of Education } & 0.02 & $0.26^{*}$ & $0.21^{*}$ & 0.05 & $-0.32^{*}$ & 0.24 \\
\hline & $(0.12)$ & $(0.16)$ & $(0.11)$ & $(0.19)$ & $(0.17)$ & $(0.30)$ \\
\hline \multicolumn{7}{|c|}{ Panel D: Household Characteristics } \\
\hline \multirow[t]{2}{*}{ Single Head } & -0.02 & 0.07 & $0.09 * \star$ & -0.02 & 0.07 & $-0.23^{\star \star \star}$ \\
\hline & $(0.03)$ & $(0.05)$ & $(0.04)$ & $(0.06)$ & $(0.06)$ & $(0.08)$ \\
\hline \multirow[t]{2}{*}{ Age of Head } & 0.29 & -0.47 & 0.46 & -0.93 & -1.5 & 0.86 \\
\hline & $(0.66)$ & $(1.24)$ & (1.09) & $(1.15)$ & $(1.14)$ & (2.33) \\
\hline \multirow[t]{2}{*}{ Years of Ed, Head } & 0.01 & 0.18 & -0.23 & 0.42 & 0.5 & -0.2 \\
\hline & $(0.19)$ & $(0.28)$ & $(0.23)$ & $(0.33)$ & $(0.40)$ & $(0.69)$ \\
\hline \multirow[t]{2}{*}{ People in Household } & 0.08 & -0.12 & -0.32 & 0.2 & -0.01 & -0.04 \\
\hline & $(0.12)$ & $(0.24)$ & $(0.20)$ & $(0.30)$ & $(0.22)$ & $(0.39)$ \\
\hline \multirow[t]{2}{*}{ Member under 18} & 0.01 & -0.08 & $-0.20^{*}$ & 0.12 & -0.1 & 0.04 \\
\hline & $(0.08)$ & $(0.16)$ & $(0.12)$ & $(0.16)$ & $(0.16)$ & $(0.27)$ \\
\hline \multicolumn{7}{|l|}{ Panel E: Poverty Measures } \\
\hline \multirow[t]{2}{*}{ Estrato } & 0.03 & 0 & -0.01 & 0.01 & 0 & 0.23 \\
\hline & $(0.05)$ & $(0.08)$ & $(0.08)$ & $(0.11)$ & $(0.10)$ & $(0.17)$ \\
\hline \multirow[t]{2}{*}{ SISBEN Score } & 0.2 & 0.24 & 0.01 & 0.23 & 0.13 & 0.46 \\
\hline & $(0.30)$ & $(0.47)$ & $(0.45)$ & (0.63) & (0.58) & (1.19) \\
\hline \multirow{2}{*}{$\begin{array}{l}\text { Household Income } \\
\text { (1,000 Pesos) }\end{array}$} & $27.14^{*}$ & -26.95 & $-56.86^{\star \star \star}$ & 29.91 & -36.83 & -6.03 \\
\hline & (15.08) & $(24.45)$ & (15.65) & $(24.40)$ & (30.19) & (47.99) \\
\hline
\end{tabular}

Note: This table presents a comparison of students in the 68 monitored schools who took the baseline survey to those that did not for each of the listed research groups. Columns 1 and 5 contains the average difference in characteristics of children in the respective control groups while columns 2, 3, 4, and 6 contain the average difference in differences between the respective control students and treatment students. Panel A contains indices of household assets (positive values indicate wealthier families). Panel B contains individual student characteristics, and Panel $\mathrm{C}$ contains characteristics of the students' families. Panel D contains poverty measures available in the SISBEN data set. This includes the "estrato" number which is a geographic measure of poverty as well as the SISBEN score which is a continuous score used to classify households for various social programs. Standard errors are clustered at the school level. * significant at the 10 percent level, ${ }^{* \star}$ at the 5 percent level, and ${ }^{* \star *}$ at the 1 percent level. 
Table A3: Comparison of Students Completing Baseline Survey

\begin{tabular}{|c|c|c|c|c|c|c|}
\hline \multirow[b]{2}{*}{ Demographic Variable } & \multicolumn{4}{|c|}{ San Cristobal } & \multicolumn{2}{|c|}{ Suba } \\
\hline & $\begin{array}{c}\text { Control } \\
\text { Average }\end{array}$ & $\begin{array}{l}\text { Basic- } \\
\text { Control }\end{array}$ & $\begin{array}{l}\text { Savings- } \\
\text { Control }\end{array}$ & $\begin{array}{c}\text { Basic- } \\
\text { Savings }\end{array}$ & $\begin{array}{c}\text { Control } \\
\text { Average } \\
\end{array}$ & $\begin{array}{l}\text { Tertiary- } \\
\text { Control }\end{array}$ \\
\hline \multicolumn{7}{|c|}{ Panel A: Indexes of Household Assets } \\
\hline Possessions & $\begin{array}{c}1.94 \\
(1.12)\end{array}$ & $\begin{array}{l}0.07^{\star *} \\
(0.03)\end{array}$ & $\begin{array}{l}-0.01 \\
(0.03)\end{array}$ & $\begin{array}{l}0.07^{\star *} \\
(0.03)\end{array}$ & $\begin{array}{c}1.93 \\
(1.01)\end{array}$ & $\begin{array}{c}0.02 \\
(0.06)\end{array}$ \\
\hline Utilities & $\begin{array}{c}4.67 \\
(1.42)\end{array}$ & $\begin{array}{l}-0.03 \\
(0.05)\end{array}$ & $\begin{array}{r}0.05 \\
(0.05)\end{array}$ & $\begin{array}{l}-0.08^{*} \\
(0.04)\end{array}$ & $\begin{array}{c}4.86 \\
(1.31)\end{array}$ & $\begin{array}{c}0.08 \\
(0.06)\end{array}$ \\
\hline Durable Goods & $\begin{array}{c}1.36 \\
(0.88)\end{array}$ & $\begin{array}{l}-0.03 \\
(0.03)\end{array}$ & $\begin{array}{c}0.03 \\
(0.03)\end{array}$ & $\begin{array}{l}-0.06^{\star *} \\
(0.03)\end{array}$ & $\begin{array}{c}1.61 \\
(0.83)\end{array}$ & $\begin{array}{c}0.07 \\
(0.05)\end{array}$ \\
\hline Physical Infrastructure & $\begin{array}{l}11.64 \\
(1.72)\end{array}$ & $\begin{array}{l}-0.10^{\star *} \\
(0.05)\end{array}$ & $\begin{array}{c}0.02 \\
(0.04)\end{array}$ & $\begin{array}{l}-0.12^{*} \\
(0.06)\end{array}$ & $\begin{array}{l}12.11 \\
(1.38)\end{array}$ & $\begin{array}{c}0 \\
(0.09)\end{array}$ \\
\hline \multicolumn{7}{|c|}{ Panel B: Individual Characteristics } \\
\hline Age & $\begin{array}{l}14.36 \\
(5.51)\end{array}$ & $\begin{array}{c}0.01 \\
(0.12)\end{array}$ & $\begin{array}{l}-0.35^{\star *} \\
(0.15)\end{array}$ & $\begin{array}{l}0.37^{\star \star \star *} \\
(0.14)\end{array}$ & $\begin{array}{l}15.54 \\
(4.18)\end{array}$ & $\begin{array}{c}0.13 \\
(0.31)\end{array}$ \\
\hline Gender & $\begin{array}{c}0.49 \\
(0.50)\end{array}$ & $\begin{array}{c}0.02 \\
(0.01)\end{array}$ & $\begin{array}{c}0 \\
(0.01)\end{array}$ & $\begin{array}{c}0.02^{*} \\
(0.01)\end{array}$ & $\begin{array}{c}0.42 \\
(0.49)\end{array}$ & $\begin{array}{c}0 \\
(0.04)\end{array}$ \\
\hline Years of Education & $\begin{array}{c}5.59 \\
(1.88)\end{array}$ & $\begin{array}{l}-0.10^{\star \star} \\
(0.04)\end{array}$ & $\begin{array}{l}-0.06 \\
(0.07)\end{array}$ & $\begin{array}{l}-0.04 \\
(0.06)\end{array}$ & $\begin{array}{c}7.45 \\
(1.25)\end{array}$ & $\begin{array}{l}-0.07 \\
(0.06)\end{array}$ \\
\hline \multicolumn{7}{|c|}{ Panel C: Household Characteristics } \\
\hline Single Head & $\begin{array}{c}0.29 \\
(0.46)\end{array}$ & $\begin{array}{c}0 \\
(0.01)\end{array}$ & $\begin{array}{c}0 \\
(0.02)\end{array}$ & $\begin{array}{c}0 \\
(0.02)\end{array}$ & $\begin{array}{r}0.25 \\
(0.43)\end{array}$ & $\begin{array}{c}0.04^{*} \\
(0.02)\end{array}$ \\
\hline Age of Head & $\begin{array}{c}45.76 \\
(10.33)\end{array}$ & $\begin{array}{r}-0.14 \\
(0.28)\end{array}$ & $\begin{array}{c}0.2 \\
(0.36)\end{array}$ & $\begin{array}{r}-0.34 \\
(0.31)\end{array}$ & $\begin{array}{l}45.75 \\
(8.54)\end{array}$ & $\begin{array}{l}0.76^{* *} \\
(0.32)\end{array}$ \\
\hline Years of Ed, Head & $\begin{array}{c}5.59 \\
(2.90)\end{array}$ & $\begin{array}{l}-0.04 \\
(0.10)\end{array}$ & $\begin{array}{l}-0.08 \\
(0.09)\end{array}$ & $\begin{array}{c}0.04 \\
(0.10)\end{array}$ & $\begin{array}{c}5.79 \\
(2.97)\end{array}$ & $\begin{array}{c}-0.14 \\
(0.13)\end{array}$ \\
\hline People in Household & $\begin{array}{c}5.39 \\
(1.91)\end{array}$ & $\begin{array}{c}0.03 \\
(0.06)\end{array}$ & $\begin{array}{c}0.02 \\
(0.06)\end{array}$ & $\begin{array}{c}0.01 \\
(0.05)\end{array}$ & $\begin{array}{r}5.13 \\
(1.62)\end{array}$ & $\begin{array}{c}0.1 \\
(0.09)\end{array}$ \\
\hline Member under 18 & $\begin{array}{c}2.59 \\
(1.32)\end{array}$ & $\begin{array}{c}0.07 \\
(0.05)\end{array}$ & $\begin{array}{c}0.03 \\
(0.04)\end{array}$ & $\begin{array}{c}0.04 \\
(0.04)\end{array}$ & $\begin{array}{c}2.37 \\
(1.18)\end{array}$ & $\begin{array}{c}0.06 \\
(0.10)\end{array}$ \\
\hline \multicolumn{7}{|l|}{ Panel D: Poverty Measures } \\
\hline Estrato & $\begin{array}{r}1.45 \\
(0.82)\end{array}$ & $\begin{array}{r}-0.01 \\
(0.03)\end{array}$ & $\begin{array}{r}-0.01 \\
(0.03)\end{array}$ & $\begin{array}{r}-0.01 \\
(0.03)\end{array}$ & $\begin{array}{c}1.65 \\
(0.76)\end{array}$ & $\begin{array}{c}0 \\
(0.04)\end{array}$ \\
\hline SISBEN Score & $\begin{array}{l}11.75 \\
(4.63)\end{array}$ & $\begin{array}{l}-0.22 \\
(0.14)\end{array}$ & $\begin{array}{c}-0.12 \\
(0.15)\end{array}$ & $\begin{array}{c}-0.1 \\
(0.14)\end{array}$ & $\begin{array}{l}13.49 \\
(4.24)\end{array}$ & $\begin{array}{c}0.22 \\
(0.28)\end{array}$ \\
\hline $\begin{array}{l}\text { Household Income } \\
\text { (1,000 Pesos) }\end{array}$ & $\begin{array}{c}364.2 \\
(235.91) \\
\end{array}$ & $\begin{array}{r}-2.15 \\
(7.92) \\
\end{array}$ & $\begin{array}{r}8.27 \\
(9.02) \\
\end{array}$ & $\begin{array}{l}-10.42 \\
(7.11) \\
\end{array}$ & $\begin{array}{r}400.27 \\
(225.45) \\
\end{array}$ & $\begin{array}{c}0.47 \\
(12.38) \\
\end{array}$ \\
\hline
\end{tabular}

Note: This table presents a comparison of students completing the baseline survey for each of the listed research groups. Columns 1 and 5 contains the average characteristics of the respective control groups while columns $2,3,4$, and 6 contain the average difference between the respective control students and treatment students. Panel A contains indices of household assets (positive values indicate wealthier families). Panel B contains individual student characteristics, and Panel C contains characteristics of the students' families. Panel D contains poverty measures available in the SISBEN data set. This includes the "estrato" number which is a geographic measure of poverty as well as the SISBEN score which is a continuous score used to classify households for various social programs. Standard errors are clustered at the school level. ${ }^{*}$ significant at the 10 percent level, ${ }^{* \star}$ at the 5 percent level, and ${ }^{* \star \star}$ at the 1 percent level. 
Table A4: Relative Differences Between Attriting and Non-Attriting Studens from Baselint

\begin{tabular}{|c|c|c|c|c|c|c|}
\hline \multirow[b]{2}{*}{ Demographic Variable } & \multicolumn{4}{|c|}{ San Cristobal } & \multicolumn{2}{|c|}{ Suba } \\
\hline & $\begin{array}{c}\text { Control } \\
\text { Difference }\end{array}$ & $\begin{array}{l}\text { Basic- } \\
\text { Control } \\
\end{array}$ & $\begin{array}{c}\text { Savings- } \\
\text { Control }\end{array}$ & $\begin{array}{c}\text { Basic- } \\
\text { Savings }\end{array}$ & $\begin{array}{c}\text { Control } \\
\text { Difference }\end{array}$ & $\begin{array}{l}\text { Tertiary- } \\
\text { Control } \\
\end{array}$ \\
\hline \multicolumn{7}{|l|}{ Panel A: Attrition Rate } \\
\hline Number Attritors & 44 & 41 & 26 & 15 & 8 & 9 \\
\hline Percentage of Baseline & $\begin{array}{c}0.02 \\
(0.15)\end{array}$ & $\begin{array}{c}0 \\
(0.01)\end{array}$ & $\begin{array}{l}-0.01^{*} \\
(0.00)\end{array}$ & $\begin{array}{c}0.01 \\
(0.01)\end{array}$ & $\begin{array}{c}0.01 \\
(0.11)\end{array}$ & $\begin{array}{c}0 \\
(0.01)\end{array}$ \\
\hline \multicolumn{7}{|c|}{ Panel B: Indexes of Household Assets } \\
\hline Possessions & $\begin{array}{l}-0.31^{\star} \\
(0.17)\end{array}$ & $\begin{array}{c}-0.1 \\
(0.17)\end{array}$ & $\begin{array}{l}-0.17 \\
(0.23)\end{array}$ & $\begin{array}{c}0.07 \\
(0.17)\end{array}$ & $\begin{array}{l}-0.31 \\
(0.36)\end{array}$ & $\begin{array}{c}0.36 \\
(0.47)\end{array}$ \\
\hline Utilities & $\begin{array}{c}-0.75^{\star \star \star} \\
(0.22)\end{array}$ & $\begin{array}{c}0.43 \\
(0.30)\end{array}$ & $\begin{array}{c}0.38 \\
(0.25)\end{array}$ & $\begin{array}{c}0.05 \\
(0.30)\end{array}$ & $\begin{array}{c}0.14 \\
(0.47)\end{array}$ & $\begin{array}{c}-1.44^{\star \star \star} \\
(0.51)\end{array}$ \\
\hline Durable Goods & $\begin{array}{l}-0.21 \\
(0.13)\end{array}$ & $\begin{array}{l}-0.01 \\
(0.22)\end{array}$ & $\begin{array}{l}-0.11 \\
(0.21)\end{array}$ & $\begin{array}{c}0.11 \\
(0.21)\end{array}$ & $\begin{array}{l}-0.49 * \\
(0.30)\end{array}$ & $\begin{array}{l}-0.08 \\
(0.33)\end{array}$ \\
\hline Physical Infrastructure & $\begin{array}{c}-0.3 \\
(0.26)\end{array}$ & $\begin{array}{l}-0.25 \\
(0.36)\end{array}$ & $\begin{array}{l}-0.45 \\
(0.43)\end{array}$ & $\begin{array}{c}0.2 \\
(0.47)\end{array}$ & $\begin{array}{c}0.14 \\
(0.49)\end{array}$ & $\begin{array}{l}-1.61^{\star \star} \\
(0.70)\end{array}$ \\
\hline \multicolumn{7}{|c|}{ Panel C: Individual Characteristics } \\
\hline Age & $\begin{array}{l}2.63^{\star \star \star} \\
(0.84)\end{array}$ & $\begin{array}{l}-2.39 \\
(2.11)\end{array}$ & $\begin{array}{l}-2.87^{\star} \\
(1.60)\end{array}$ & $\begin{array}{r}0.48 \\
(1.29)\end{array}$ & $\begin{array}{r}0.46 \\
(1.49)\end{array}$ & $\begin{array}{l}-1.15^{\star} \\
(0.64)\end{array}$ \\
\hline Gender & $\begin{array}{c}0.11 \\
(0.08)\end{array}$ & $\begin{array}{l}-0.15 \\
(0.11)\end{array}$ & $\begin{array}{l}-0.13 \\
(0.13)\end{array}$ & $\begin{array}{r}-0.02 \\
(0.12)\end{array}$ & $\begin{array}{l}-0.30^{\star} \\
(0.18)\end{array}$ & $\begin{array}{c}0.1 \\
(0.20)\end{array}$ \\
\hline Years of Education & $\begin{array}{l}-0.28 \\
(0.29)\end{array}$ & $\begin{array}{c}0.32 \\
(0.45)\end{array}$ & $\begin{array}{r}0.28 \\
(0.67)\end{array}$ & $\begin{array}{c}0.04 \\
(0.53)\end{array}$ & $\begin{array}{l}1.31^{\star \star \star} \\
(0.44)\end{array}$ & $\begin{array}{l}-1.25^{\star \star} \\
(0.57)\end{array}$ \\
\hline \multicolumn{7}{|c|}{ Panel D: Household Characteristics } \\
\hline Single Head & $\begin{array}{l}-0.09 \\
(0.07)\end{array}$ & $\begin{array}{l}0.19 * * \\
(0.09)\end{array}$ & $\begin{array}{r}0.19 \\
(0.12)\end{array}$ & $\begin{array}{c}0 \\
(0.15)\end{array}$ & $\begin{array}{r}0.13 \\
(0.15)\end{array}$ & $\begin{array}{c}0.03 \\
(0.17)\end{array}$ \\
\hline Age of Head & $\begin{array}{l}-1.45 \\
(1.57)\end{array}$ & $\begin{array}{l}-3.77^{\star \star} \\
(1.75)\end{array}$ & $\begin{array}{c}2.97 \\
(2.27)\end{array}$ & $\begin{array}{c}-6.74^{\star \star \star} \\
(2.52)\end{array}$ & $\begin{array}{c}0 \\
(3.04)\end{array}$ & $\begin{array}{l}-6.18^{*} \\
(3.38)\end{array}$ \\
\hline Years of Ed, Head & $\begin{array}{l}0.89 * * \\
(0.44)\end{array}$ & $\begin{array}{l}-0.82 \\
(0.64)\end{array}$ & $\begin{array}{l}-0.81 \\
(0.65)\end{array}$ & $\begin{array}{l}-0.01 \\
(0.82)\end{array}$ & $\begin{array}{c}0.6 \\
(1.06)\end{array}$ & $\begin{array}{l}-0.57 \\
(1.28)\end{array}$ \\
\hline People in Household & $\begin{array}{r}0.06 \\
(0.29)\end{array}$ & $\begin{array}{c}-0.4 \\
(0.34)\end{array}$ & $\begin{array}{l}-0.21 \\
(0.38)\end{array}$ & $\begin{array}{l}-0.19 \\
(0.33)\end{array}$ & $\begin{array}{l}-0.38 \\
(0.58)\end{array}$ & $\begin{array}{l}-0.42 \\
(0.81)\end{array}$ \\
\hline Member under 18 & $\begin{array}{l}-0.09 \\
(0.20)\end{array}$ & $\begin{array}{r}0.29 \\
(0.38)\end{array}$ & $\begin{array}{c}0.24 \\
(0.39)\end{array}$ & $\begin{array}{r}0.05 \\
(0.24)\end{array}$ & $\begin{array}{c}0.14 \\
(0.42)\end{array}$ & $\begin{array}{l}-0.34 \\
(0.75)\end{array}$ \\
\hline \multicolumn{7}{|l|}{ Panel E: Poverty Measures } \\
\hline Estrato & $\begin{array}{c}-0.34^{* * *} \\
(0.12)\end{array}$ & $\begin{array}{c}0.17 \\
(0.19)\end{array}$ & $\begin{array}{c}0.24 \\
(0.22)\end{array}$ & $\begin{array}{l}-0.07 \\
(0.20)\end{array}$ & $\begin{array}{c}0.11 \\
(0.27)\end{array}$ & $\begin{array}{c}-0.99 * \star * \\
(0.31)\end{array}$ \\
\hline SISBEN Score & $\begin{array}{l}-1.55^{\star \star} \\
(0.70)\end{array}$ & $\begin{array}{c}0.97 \\
(0.99)\end{array}$ & $\begin{array}{c}1.01 \\
(1.06)\end{array}$ & $\begin{array}{r}-0.04 \\
(1.32)\end{array}$ & $\begin{array}{r}-0.81 \\
(1.51)\end{array}$ & $\begin{array}{l}-2.85^{\star} \\
(1.52)\end{array}$ \\
\hline $\begin{array}{c}\text { Household Income } \\
\text { (1,000 Pesos) }\end{array}$ & $\begin{array}{c}-0.78 \\
(35.97) \\
\end{array}$ & $\begin{array}{r}-47.15 \\
(49.78) \\
\end{array}$ & $\begin{array}{r}-27.64 \\
(57.45) \\
\end{array}$ & $\begin{array}{r}-19.51 \\
(45.92) \\
\end{array}$ & $\begin{array}{r}-91.98 \\
(80.22) \\
\end{array}$ & $\begin{array}{r}77.88 \\
(65.14) \\
\end{array}$ \\
\hline
\end{tabular}

Note: This table presents a comparison of students who took the baseline survey and the follow up survey to those that only took the baseline survey for each of the listed research groups. Columns 1 and 5 contains the average difference in characteristics of children in the respective control groups while columns $2,3,4$, and 6 contain the average difference in differences between the respective control students and treatment students. Panel A contains indices of household assets (positive values indicate wealthier families). Panel B contains individual student characteristics, and Panel C contains characteristics of the students' families. Panel D contains poverty measures available in the SISBEN data set. This includes the "estrato" number which is a geographic measure of poverty as well as the SISBEN score which is a continuous score used to classify households for various social programs. Standard errors are clustered at the school level. * significant at the 10 percent level, ** at the 5 percent level, and

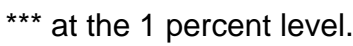

